\title{
PRICE DISCRIMINATION AND PRICING-TO-MARKET BEHAVIOR OF BLACK SEA REGION WHEAT EXPORTERS
}

\author{
GULMIRA GAFAROVA* \\ Leibniz Institute of Agricultural Development in Transition Economies (IAMO), 06120 Halle (Saale), Germany \\ OLEKSANDR PEREKHOZHUK** \\ Leibniz Institute of Agricultural Development in Transition Economies (IAMO), 06120 Halle (Saale), Germany \\ THOMAS GLAUBEN*** \\ Leibniz Institute of Agricultural Development in Transition Economies (IAMO), 06120 Halle (Saale), Germany
}

\begin{abstract}
Substantial changes in the world wheat market have resulted in a shift in the market shares of the main wheat exporting countries. Since 2002, Kazakhstan, Russia, and Ukraine (KRU) have become important wheat exporters on the world market, and their pricing behavior has become a vital issue. By applying the pricing-to-market model to wheat exports, this study analyzes the price-discriminating behavior of KRU wheat exports from 1996 to 2012. The results demonstrate that KRU are able to exercise price discrimination in some importing countries, but in most they either face perfect competition or set common markups in imperfectly competitive markets.
\end{abstract}

Keywords. Fixed-effects model, markup pricing, price discrimination, pricing-to-market, wheat export

JEL Classifications. L13, Q11, Q17, Q18

\section{Introduction}

Wheat plays a central role in satisfying the world's growing demand for foodstuffs, as it is one of the most important food staples. Because of natural and climatic conditions, most countries in the world are not able to produce sufficient quantities of wheat to satisfy domestic demand and thus import it from

The authors thank the editor, Andrew McKenzie, and the anonymous reviewers for their helpful comments and suggestions on earlier versions of this paper. This study was supported by the Volkswagen Foundation through MATRACC Project "The Global Food Crisis - Impact on Wheat Markets and Trade in the Caucasus and Central Asia and the Role of Kazakhstan, Russia and Ukraine.”

*E-mail: gafarova@iamo.de

**Corresponding author: E-mail: perekhozhuk@iamo.de

***E-mail: glauben@iamo.de 


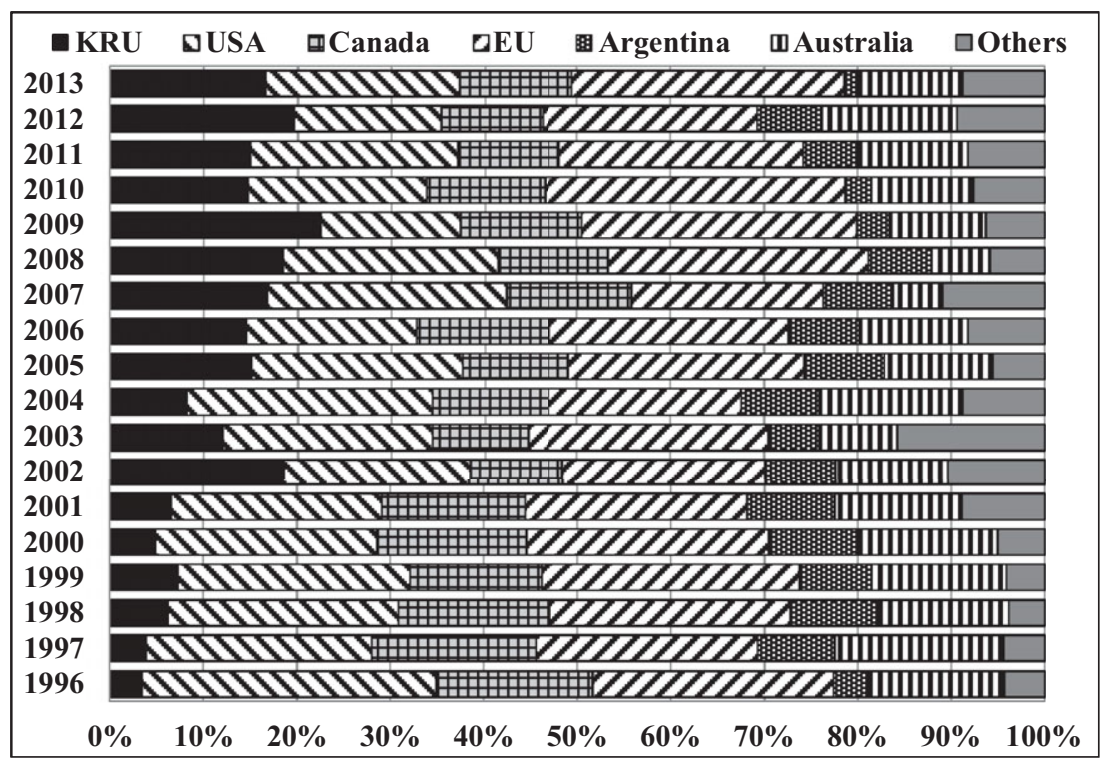

Figure 1. Market Shares of the Major Wheat Exporting Countries, 1996-2013 (source: FAOSTAT (2015) for 1996-2011 data and UN Comtrade Database (2015) for 2012-2013 data; "EU" indicates only the main wheat exporting countries in the European Union, including Belgium, Bulgaria, Czech Republic, Denmark, France, Germany, Hungary, Latvia, Lithuania, Poland, Romania, and the United Kingdom; "KRU” indicates Kazakhstan, Russia, and Ukraine)

wheat exporting countries. Consequently, decisions by wheat exporting countries concerning export quantities and prices are vital issues for global food security. Historically, Argentina, Australia, Canada, the European Union (EU), and the United States (USA) have been major wheat exporters in the world market. However, the collapse of the Soviet Union led the resulting countries' newly established economies to implement restructuring policies in their agricultural production, consumption, and trade sectors during the 1990s. Because of an increase in yields, some countries achieved a massive increase in grain production, especially in wheat production, during the 2000s. This led to an increase in wheat exports from the former Soviet countries-namely, Kazakhstan, Russia, and Ukraine (KRU). Consequently, since 2002, KRU countries, also known as Black Sea region countries, have participated in the world market as important wheat exporters (Liefert, Liefert, and Luebehusen, 2013).

The KRU countries were able to increase their market share from $3 \%$ in 1996 to $18 \%$ in 2002 (see Figure 1). This share briefly peaked at $22 \%$ in 2009 and later declined to $17 \%$ in 2013 , but it is still higher than the shares of all other competitors except the EU and the USA. Although KRU countries are gaining rapidly in the world wheat market, their market share is very unstable 
because of their weather-dependent production and periodically applied export restriction policies. This instability affects their reputation in the world market and has given them the stigma of being unreliable as wheat suppliers. Thus, most importing countries usually have short-term contracts with the KRU countries. The fluctuations in KRU's market share also affect the shares of various wheat exporters in the world market. Although the total share of the traditional wheat exporters was $75 \%$ in 2014 , it is expected to be $60 \%$ in $2023-2024$ because of an increase in KRU's export share (USDA, 2014). Hence, the upward trend in KRU's share is expected to continue because these countries have not yet reached their limits of production capacities and still have the potential to expand grain areas and increase wheat yields (Tothova, Meyers, and Goychuk, 2013). It is projected that KRU's market share will reach $26 \%$ by 2023 (OECD/FAO, 2014).

As KRU countries become larger wheat exporters in the world wheat market, it is expected that their role in decisions concerning wheat prices in various importing markets will become more influential. Exporting countries can charge different prices in different importing countries for a number of reasons, the foremost being changes in bilateral exchange rates, relations with importing countries, geographic locations of importing countries, and the number of competitors in destination markets. Making decisions concerning export prices based on these reasons is called exercising price discrimination. However, there is one special type of price discrimination, called pricing-to-market (PTM), in which the ratio of prices paid by the importer is affected through the changes in bilateral exchange rates between an exporter and its importers (Pall et al., 2013).

The quantities of KRU wheat exports sent to various destinations are not the same. Because of historical relations and geographic locations, some importing countries are important trade partners for KRU. However, most countries buy wheat from various exporting countries to diversify their wheat imports. The bilateral exchange rates between importing and exporting countries are generally volatile. This study aims to examine the effect of bilateral exchange rate fluctuations on the decisions KRU countries make concerning wheat prices. Specifically, the goal of this study is to investigate (1) whether KRU countries were able to price discriminate in selected importing markets during the period 1996-2012, (2) how KRU exporters adjust their prices in response to variations in exchange rates, and (3) how pricing strategies differ among the exporting countries.

The rest of the article is organized as follows. Section 2 covers the country background, and Section 3 summarizes previous relevant studies. An econometric analysis of the empirical model is presented in Section 4. Section 5 describes the data analysis and the results of the panel unit root tests. The estimations of the PTM model are presented in Section 6. The final section of the article provides general conclusions and policy implications. 


\section{Country Background}

There are two main reasons why KRU countries have become large wheat exporters. The first reason is that after the collapse of the Soviet Union, the newly established economies restructured their agricultural sectors, especially regarding agricultural production, consumption, and trade during the 1990s. When they were a part of the Soviet Union, KRU countries were not wheat exporters, but rather wheat importers. Livestock was the prioritized sector, and the government imported grain from other countries to meet the demand for feed grain. After the breakdown of the Soviet Union, KRU countries did not continue supporting the livestock sector (to do so would have been very costly) but worked to improve the grain sector, in which they had comparative advantages in the world market. Consequently, domestic livestock production decreased, and grain production increased (Liefert, Liefert, and Luebehusen, 2013).

The second reason KRU countries have become large wheat exporters is that because of higher yields, KRU's wheat production increased substantially during the 2000s. The newly established large companies were interested in investing, especially in the grain sector, and they applied different technologies and better management practices. Consequently, higher yields were achieved in grain production, and this led to an increase in KRU's wheat exports (Liefert, Liefert, and Luebehusen, 2013).

Kazakhstan is a landlocked country without direct access to the world market. However, it is a leading wheat producer and exporter in Central Asia. According to UN Comtrade statistics, Kazakhstan was the third-largest wheat exporter among the Commonwealth of Independent States economies, behind only Russia and Ukraine in 2013. Russia was previously a net wheat importer, but in 2002 it became a net wheat exporter and in 2013 was the fifth-largest wheat exporter in the world. Ukraine takes advantage of its geographic proximity to the EU and the Middle East and North African (MENA) ${ }^{1}$ countries and in 2013 was the seventh-largest wheat exporter in the world.

The KRU countries' wheat production is highly dependent on weather conditions, and these countries also occasionally implement export restriction policies. For instance, because of a severe winter in Russia and Ukraine in 2003, and a harsh drought in Kazakhstan in 2004, wheat production and export in these countries declined substantially (see Figure 2). However, because of favorable weather after 2003 and new wheat stocks, Ukrainian wheat exports peaked to 12.9 million metric tons in 2009 (FAO/EBRD, 2010). Later, all KRU countries faced severe drought in 2010. Again, after 2 years, the severe drought significantly decreased Kazakh expected wheat production and potential wheat exports.

1 The MENA region refers to the following countries and territories: Algeria, Bahrain, Egypt, Iran, Iraq, Israel, Jordan, Kuwait, Lebanon, Libya, Morocco, Oman, Qatar, Saudi Arabia, Syria, Tunisia, United Arab Emirates, West Bank and Gaza, and Yemen. 


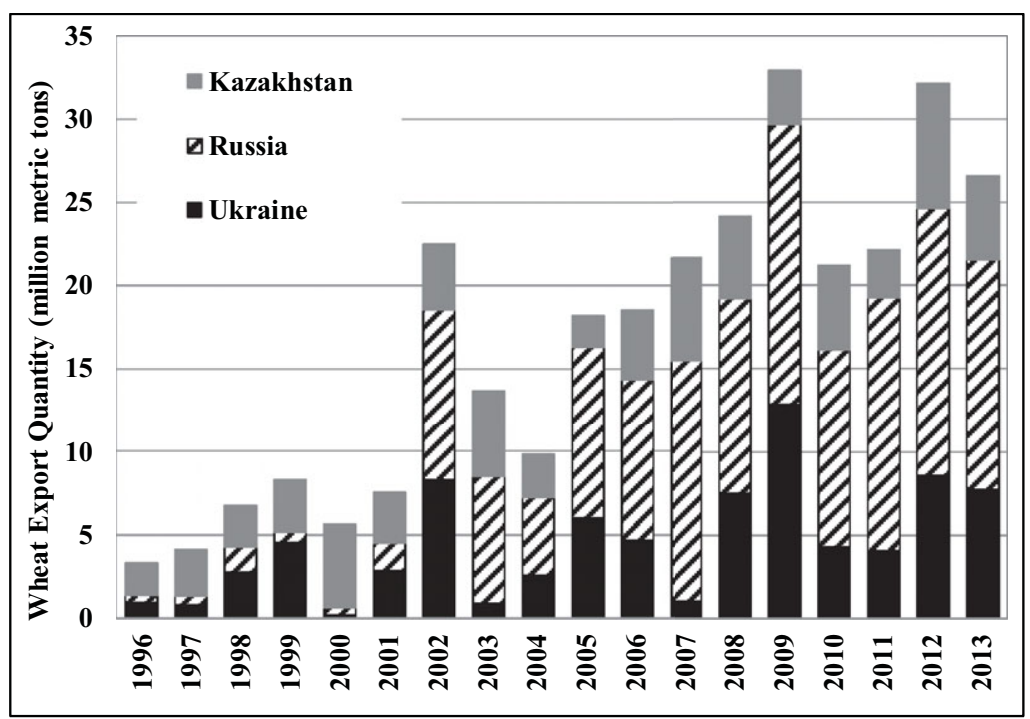

Figure 2. Annual KRU Wheat Export Quantity, 1996-2013 (source: UN Comtrade, 2015)

Similar to weather conditions, export restrictions, which were implemented during the high-price phases in 2007-2008 and 2010-2011, limited wheat trade and led to a decline in KRU's market shares. Specifically, Kazakhstan applied export bans on wheat from April until September 2008 (Kim, 2010). Russia introduced export taxes on wheat in 2007-2008 and, because of small wheat crops, totally banned wheat exports in 2010-2011. Similarly, during both price peaks, Ukraine set export quotas within a governmental license system (Götz, Glauben, and Brümmer, 2013). Despite all these issues, KRU countries were able to maintain an increasing trend in wheat production. In fact, KRU countries have a good chance to further their positions as important wheat exporters in the world grain market in the future. According to forecasts, KRU countries will export 52 million metric tons of wheat by 2023-2024, despite an increase in domestic consumption (USDA, 2014).

\section{Related Literature}

One of the characteristics of new trade theory is imperfect competition. Under this condition, a profit-maximizing exporter has the chance to exercise price discrimination in an importing market only if the importer's residual demand elasticity is inelastic (because of an absence of other suppliers or an inelastic demand). Otherwise, if residual demand is elastic, price discrimination cannot occur (Pall et al., 2013). Similarly, Carew and Florkowski (2003) argue that an exporter's ability to price discriminate depends both on the elasticity of demand that the exporter faces in different importing countries and on its relationship to 
the common marginal cost. Moreover, Lavoie and Liu (2007) claim that changes in exchange rate affect the pricing behavior of an exporter in an imperfectly competitive market because these changes create large gaps between the prices set by the seller and those paid by the buyer, which consequently causes price discrimination. Price discrimination occurs when an exporter sets different markups across the destination countries to adjust to variations in exchange rates. If the exporting country's currency depreciates, import prices do not necessarily change proportionally, and thus relative world prices can be affected. Against this background, an export price implicitly contains a destination-specific markup over marginal cost; that is, exporters charge the importing countries on an individual basis according to the importers' demand characteristics (Pall et al., 2013).

Krugman (1987) was the first to describe a special type of price discrimination, called PTM. In order to provide an overview of the literature that examines exporters' pricing behavior in the selected importing countries, Table A1 in the Appendix details all relevant studies. Most studies focus their investigation on the pricing strategies of Australian, Canadian, European, and U.S. agricultural food (especially grain) exporters during various time periods and find some evidence of price discrimination exercised in destination countries (Brown, 2001; Carew, 2000; Carew and Florkowski, 2003; Glauben and Loy, 2003; Griffith and Mullen, 2001; Jin, 2008; Knetter, 1989, 1993). More precisely, by applying the PTM framework to quarterly data, Pick and Park (1991) and Pick and Carter (1994) confirm that U.S. and Canadian wheat exporters exercised price discrimination in certain destinations during the 1980s and 1990s. These findings are in line with those reported almost two decades later by Jin and Miljkovic (2008). These authors found that U.S. wheat exporters are still influential enough in the wheat markets to exercise price discrimination. Carew and Florkowski (2003) differentiate the pricing strategies between U.S. and Canadian wheat exporters and argue that in most destination countries the USA stabilizes local currency prices, whereas Canada amplifies the effect of exchange rate changes. Although there are different methods to determine whether the exporting countries exercise price discrimination in the destination countries, most studies prefer a fixed-effects panel method (Carew, 2000; Carew and Florkowski, 2003; Falk and Falk, 2000; Fedoseeva, 2013; Gil-Pareja, 2002; Jin, 2008; Jin and Miljkovic, 2008; Knetter, 1989; Pall et al., 2013; Pick and Carter, 1994; Pick and Park, 1991).

Despite the extensive literature on the PTM model, to our knowledge no other study, except Pall et al. (2013), has analyzed the KRU's pricing behavior in the world wheat market. Pall et al. (2013) consider the PTM model only for the Russian wheat exporters and conclude that even though Russia exports wheat to many destinations on a large scale, it can only exercise price discrimination in a few of them. Russia is unlikely to exert significant market power in the world wheat market because it faces perfect competition in most importing countries. 


\section{Modeling Approach}

This study focuses on the application of a testable hypothesis to determine whether KRU countries exercise price discrimination in destination markets by using the PTM model. This model provides a suitable framework for modeling imperfect competition by indicating the competitiveness of an exporter, as it is connected to markup over marginal cost (Jin and Miljkovic, 2008). However, it cannot account for uncertainty and adjustment costs and is not able to distinguish between temporary and permanent exchange rate changes (Carew, 2000).

The PTM model introduced by Krugman (1987) and developed further by Knetter (1989) to determine the presence of price discrimination in international trade is applied in this study:

$$
\ln p_{i t}=\lambda_{i}+\theta_{t}+\beta_{i} \ln e_{i t}+u_{i t}, \forall i=1, \ldots, N \text { and } \forall t=1, \ldots, T,
$$

where $p_{i t}$ is the wheat export price paid by an importing country $i$ measured in the exporting country's currency (Kazakhstani tenge, ${ }^{2}$ Russian ruble, ${ }^{3}$ and Ukrainian hryvnia $^{4}$ per metric ton) in period $t ; \lambda_{i}$ and $\theta_{t}$ represent country and time effects, respectively; and $e_{i t}$ is the destination-specific exchange rate expressed as the importing country's currency per unit of exporting country's currency. The parameter $\beta_{i}$ denotes the elasticity of the export price with respect to exchange rate. The sign of $\beta$ refers to various policies implemented by an exporter; that is, a significantly negative $\beta$ means that an exporter stabilizes local currency prices, whereas a significantly positive $\beta$ indicates that an exporter amplifies the effect of exchange rate changes. Specifically, positive coefficients of the exchange rate variable show that demand for wheat imports becomes more inelastic as export prices increase in response to the depreciation of an importing country's currency relative to an exporting country's currency. On the contrary, negative coefficients of the exchange rate variable indicate that demand for wheat imports becomes more inelastic as export prices decrease because of the depreciation of an importing country's currency relative to an exporting country's currency (Jin and Miljkovic, 2008). Finally, $u_{i t}$ is the independent and identically distributed (i.i.d.) error term $N\left(0, \sigma_{u}^{2}\right)$.

The model described in equation (1) differentiates two types of price adjustments: marginal cost (time effect) and price markup over marginal cost (defined by destination-specific exchange rate; Carew and Florkowski, 2003).

With respect to model parameters, Knetter (1989) distinguished three alternative model scenarios. First, a competitive market, in which changes in exchange rate do not influence export prices $(\beta=0)$, there is no country effect $(\lambda=0)$ and the export price $\left(\theta_{t} \neq 0\right)$ is the same across destinations. The

2 Kazakhstani tenge: November 15, 1993-present ( 1 tenge $=500$ Soviet rubles).

3 Russian new ruble (redenominated): January 1, 1998-present ( 1 new ruble $=1,000$ old rubles).

4 Ukrainian hryvnia: September 2, 1996-present. 
second and third situations explicitly introduce imperfect competition with price discrimination across destination countries. In detail, the second model is called price discrimination with constant elasticity of demand with respect to domestic currency prices. In this model, the shifts in bilateral exchange rates do not affect export prices across destinations $(\beta=0)$, and markup over marginal cost is constant but can change over time and across destinations $(\lambda \neq 0$ and $\theta \neq 0)$. Hence, the time effects capture the changes in marginal cost, and the country effect measures the markups in different destinations. The third model is called price discrimination with varying elasticities of demand with respect to domestic currency prices. More precisely, the changes in exchange rate affect a destinationspecific markup over marginal $\operatorname{costs}(\lambda \neq 0)$, and thus export prices depend on changes in exchange rate $(\beta \neq 0)$. This situation is called PTM.

In short, it can be summarized that “... how exchange rates affect commodity export prices depends on how changes in currency values are transmitted to foreign currency prices" (Carew and Florkowski, 2003, p. 139). Depending on the elasticity of demand, changes in exchange rates have different effects on export prices. If the elasticity of demand with respect to price is constant, then changes in exchange rates will not have any effect on the optimal markup charged by an exporter but will change the price paid by an importing country. However, if the elasticity of demand with respect to price is not constant, then shifts in exchange rates will change the optimal markup charged by an exporter; that is, the local currency price paid by an importing country will change.

\section{Data Analysis and Descriptive Statistics}

The model in equation (1) is applied to the wheat market in order to investigate noncompetitive market structures in Kazakh, Russian, and Ukrainian wheat exports. Three separate panel data sets are used, consisting of the average annual exchange rates and export unit values for Kazakhstan, Russia, and Ukraine for the period 1996-2012. The harmonized system (HS) code description for wheat is categorized as "wheat and meslin" (HS code ${ }^{5}$ : 1001), which includes durum wheat, and wheat (except durum wheat) and meslin.

Unit value data are calculated by dividing export volume (in U.S. dollars) by export quantity (in metric tons), both of which are provided by United Nations Commodity Trade Statistics Database (UN Comtrade, 2015). This procedure entails a loss of information because the generated unit values usually contain aggregated data concerning products for different uses and thus of different qualities. In other words, by resorting to unit values, the qualities of the products shipped to different destinations are accepted as the same and constant over time (Lavoie and Liu, 2007). More precisely, as the price data used in this study

5 For commodity classifications and quantity measurement, see United Nations, Department of Economic and Social Affairs, Statistics Division (2011), pp. 31-37, 45-46. 
represent export unit values, but not real export prices, it should be clarified that the changes in export prices to different destinations are because of the pricing strategies of the exporters, not because of differences in quality (Fedoseeva, 2013). In contrast, Knetter (1989) argues that as different qualities of wheat are shipped to different countries, country dummies would cover the quality issue. Similarly, time effects would capture the changes in quality over time (Lavoie and Liu, 2007).

All value data are "free on board"; that is, the export prices include the costs of transaction, transportation, and any other services performed to deliver goods to the border of an exporting country. ${ }^{6}$ Hence, significant variations in export prices for different destinations cannot be explained by different transportation costs.

The average annual nominal exchange rate data are available from IMF (2015), OANDA (2015), and ROSSTAT (2001, 2007, 2013). The exchange rate data for Tajikistan, ${ }^{7}$ Turkmenistan, ${ }^{8}$ and Uzbekistan ${ }^{9}$ are calculated by converting old currencies into new ones. Similarly, the exchange rate data for the EU countries that accepted the euro in 1999 are fixed to the euro for the period 1996-1998.

Turning to descriptive statistics, the model comprises $T \times N$ observations. To avoid singularity problems, $T-1$ time dummies $\left(\theta_{t}\right)$ and $N-1$ country dummies $\left(\lambda_{i}\right)$ are included in a pooled cross-sectional-time-series model. Intercept countries were chosen that have both seaports and highly competitive wheat markets: Turkey for Kazakhstan and Israel for Russia and Ukraine. Importing countries were selected based on data availability, number of observations (more than three observations), geographic location, and relative importance to the exporting country. The number of destination countries for Kazakhstan, Russia, and Ukraine is 48, 71, and 65, respectively. Descriptive statistics for destinationspecific export prices and bilateral exchange rates are presented in Tables A2-A4 in the Appendix. The data are considered to be an unbalanced panel because KRU countries do not trade with all importing countries in every observed year.

\section{Estimation Results and Discussion}

As this study is based on panel data, nonstationarity should be checked, which is particularly necessary in the case of a large number of observations and

6 For statistical values of exported goods and terms of delivered goods, see United Nations, Department of Economic and Social Affairs, Statistics Division (2011), pp. 39-41, 97-99.

7 Tajikistani ruble: May 10, 1995-October 29, 2000 (1 Tajikistani ruble = 100 Russian rubles); Tajikistani somoni: October 30, 2000-present (1 Tajikistani somoni = 1,000 Tajikistani rubles).

8 Turkmen old manat (TMM): November 1, 1993-December 31, 2008 (1 manat = 500 Russian rubles); Turkmen new manat (TMT): January 1, 2009-present (1 TMT = 5,000 TMMs).

9 Uzbekistan old som: November 15, 1993-July 1, 1994; new som: July 1, 1994-present (1 new som $=1,000$ old soms). 
Table 1. Fisher-Type Augmented Dickey Fuller Panel Unit Root Tests

\begin{tabular}{|c|c|c|c|c|c|c|}
\hline \multirow{4}{*}{$\begin{array}{l}\text { Test } \\
\text { Specification }\end{array}$} & \multicolumn{6}{|c|}{ Inverse Normal Statistics } \\
\hline & \multicolumn{2}{|c|}{ Kazakhstan } & \multicolumn{2}{|c|}{ Russia } & \multicolumn{2}{|c|}{ Ukraine } \\
\hline & Export & Exchange & Export & Exchange & Export & Exchange \\
\hline & Price & Rate & Price & Rate & Price & Rate \\
\hline Drift & $-5.94^{* * *}$ & $-7.87^{* * *}$ & $-6.33^{* * *}$ & $-13.03^{* * *}$ & $-5.32^{* * *}$ & $-9.00^{* * *}$ \\
\hline Demean & $-9.82^{* * *}$ & $-4.14^{* * *}$ & $-10.95^{* * *}$ & $-3.30^{* * *}$ & $-11.44^{* * *}$ & $-3.63^{* * *}$ \\
\hline Demeaned with drift & $-11.31^{* * *}$ & $-8.90^{* * *}$ & $-14.01^{* * *}$ & $-10.93^{* * *}$ & $-13.35^{* * *}$ & $-9.88^{* * *}$ \\
\hline Trend & $-4.43^{* * *}$ & -0.45 & -0.65 & $-2.92^{* *}$ & $-2.57^{* *}$ & $-2.81^{* *}$ \\
\hline Demeaned with trend & $-9.28^{* * *}$ & $-4.08^{* * *}$ & $-12.03^{* * *}$ & $-2.44^{*}$ & $-6.27^{* * *}$ & 1.57 \\
\hline
\end{tabular}

Notes: The lag length is zero. Asterisks ${ }^{* * *}{ }^{* *}$, and ${ }^{*}$ refer to statistical significance at the $1 \%, 5 \%$, and $10 \%$ levels, respectively.

Table 2. Fisher-Type Phillips-Perron Panel Unit Root Tests

\begin{tabular}{|c|c|c|c|c|c|c|}
\hline \multirow{4}{*}{$\begin{array}{l}\text { Test } \\
\text { Specification }\end{array}$} & \multicolumn{6}{|c|}{ Inverse Normal Statistics } \\
\hline & \multicolumn{2}{|c|}{ Kazakhstan } & \multicolumn{2}{|c|}{ Russia } & \multicolumn{2}{|c|}{ Ukraine } \\
\hline & Export & Exchange & Export & Exchange & Export & Exchange \\
\hline & Price & Rate & Price & Rate & Price & Rate \\
\hline Demean & $-9.82^{* * *}$ & $-4.14^{* * *}$ & $-10.95^{* * *}$ & $-3.30^{* * *}$ & $-11.44^{* * *}$ & $-3.63^{* * *}$ \\
\hline Trend & $-4.43^{* * *}$ & -0.45 & -0.65 & $-2.92^{* *}$ & $-2.57^{* *}$ & $-2.81^{* *}$ \\
\hline Demeaned with trend & $-9.28^{* * *}$ & $-4.08^{* * *}$ & $-12.03^{* * *}$ & $-2.44^{*}$ & $-6.27^{* * *}$ & 1.57 \\
\hline
\end{tabular}

Notes: The lag length is zero. Asterisks ${ }^{* * *},{ }^{* *}$, and ${ }^{*}$ refer to statistical significance at the $1 \%, 5 \%$, and $10 \%$ levels, respectively.

long time periods (Baltagi, 2005). We perform Augmented Dickey-Fuller and Phillips-Perron panel unit root tests on export prices and nominal exchange rates. Moreover, as the data are unbalanced panels, a Fisher-type panel unit root test is applied in this study. The idea behind a panel unit root test is to check the null hypothesis of nonstationarity $[\mathrm{I}(1)]$ against the alternative of stationarity $[\mathrm{I}(0)]$. The results of the tests are presented in Tables 1 and 2.

The test results with drift, demean, and demeaned with drift indicate that the null hypothesis of nonstationarity is rejected; that is, none of the panels contains a unit root. This rejection leads to the conclusion that there exists a linear longrun relationship between export prices and destination-specific exchange rates and confirms the existence of PTM.

Additionally, the Wooldridge test for autocorrelation in panel data (Wooldridge, 2002) was conducted. The results fail to prove the null hypothesis of no serial correlation; that is, it is assumed that there is first-order autocorrelation in the data. 
Table 3. F-Test Results

\begin{tabular}{llll}
\hline \hline Null Hypothesis & Kazakhstan & Russia & Ukraine \\
\hline$H_{0}: \lambda_{1}=\lambda_{2}=\cdots=\lambda_{i}$ & $4.49^{* *}$ & $15.73^{* * *}$ & $41.33^{* * *}$ \\
$H_{0}: \beta_{1}=\beta_{2}=\cdots=\beta_{i}=0$ & $4.75^{\text {** }}$ & $20.17^{* * *}$ & $31.92^{* * *}$ \\
\hline \hline
\end{tabular}

Notes: The letter $i$ denotes number of importing countries. Asterisks ${ }^{* * *}$, **, and ${ }^{*}$ refer to statistical significance at the $1 \%, 5 \%$, and $10 \%$ levels, respectively.

Two types of $F$-tests are employed to verify the joint significance of both country effects and the exchange rate effects for each exporting country separately (see Table 3). The null hypotheses that all country effects are equal and all exchange rate effects are zero (the case of the perfect market) are rejected for all exporting countries; that is, KRU wheat exporters set country-specific markups and use PTM behavior in at least one of the importing countries.

The PTM model is estimated by using the fixed-effects model for each exporting country separately. Because the unit root process is rejected, we can apply the fixed-effects model to the panel data.

According to Tables $4-6$, there is evidence of PTM by KRU countries in the destination markets (i.e., the null hypothesis of a constant elasticity model is rejected). Kazakh wheat exporters use PTM behavior (significant $\beta$ ) in 7 out of 48 importing countries (see Table 4). Specifically, they stabilize the local currency prices (significantly negative $\beta$ ) in Albania, Greece, Lebanon, Tajikistan, and Uzbekistan but amplify the effect of destination-specific exchange rate changes in Lithuania and Sudan.

Additionally, Kazakh exporters price discriminate with constant markups against Iran (significant $\lambda$, insignificant $\beta$ ); that is, they charge higher price markups than Turkey (intercept country). However, in 40 destinations there is no evidence of price discrimination exercised by Kazakh exporters; that is, they either face perfect competition or set common markups in imperfectly competitive markets. Because Kazakhstan is located far from most of its destinations, transportation costs make Kazakh wheat less competitive. Most countries prefer to import from short-distance exporters, and this restricts the Kazakh exporters' ability to exercise price discrimination.

The PTM results listed in Table 4 should be carefully explained because there are differences between small and large buyers. Moreover, there are several consistent markets for Kazakhstan where Kazakh exporters export in large quantities-namely, Iran, Tajikistan, and Uzbekistan. However, only in Iran do they enjoy a small price premium ${ }^{10}(1 \%)$, whereas in Tajikistan $(-13 \%)$

10 As Turkey was accepted as an intercept country for Kazakhstan, the average price for Turkey was considered as a benchmark price for calculating the price premium. Similarly, Israel was accepted as an intercept country for Russia and Ukraine. Further, the average price for Israel was used as a benchmark price for calculating the price premiums for Russia and Ukraine. 
Table 4. Pricing-to-Market Results for Kazakhstan

\begin{tabular}{|c|c|c|c|c|c|}
\hline \multicolumn{2}{|c|}{ Destinations $\lambda$} & \multirow{2}{*}{$\frac{\beta}{-0.23[-0.82]}$} & \multirow{2}{*}{$\begin{array}{l}\text { Destinations } \\
\text { Lithuania }\end{array}$} & $\lambda$ & $\beta$ \\
\hline Afghanistan & $0.11[0.23]$ & & & $1.24[1.72]$ & $0.40^{*}[1.98]$ \\
\hline Albania & $-2.34^{* *}[-2.15]$ & $-7.93^{* *}[-2.60]$ & Malaysia & $0.00[0.00]$ & $-0.08[-0.40]$ \\
\hline Algeria & $0.01[0.01]$ & $-1.84[-0.93]$ & Moldova & $-2.75[-1.09]$ & $-1.24[-1.15]$ \\
\hline Azerbaijan & $1.92[1.52]$ & $0.40[1.56]$ & Mongolia & $0.92[1.03]$ & $-0.08[-0.19]$ \\
\hline Belarus & $0.43[1.23]$ & $0.09[1.62]$ & Morocco & $4.71[0.98]$ & $1.73[0.97]$ \\
\hline Cyprus & 1.48 [1.39] & 0.28 [1.39] & Netherlands & $-2.40[-0.75]$ & $-0.63[-0.91]$ \\
\hline China & $3.25[0.51]$ & $0.95[0.47]$ & Norway & $0.68[0.77]$ & $0.19[0.65]$ \\
\hline Dominica & 1.17 [1.33] & $0.30[1.36]$ & Pakistan & 0.17 [0.39] & $-0.27[-0.62]$ \\
\hline Egypt & $-0.89[-0.99]$ & $-0.27[-1.00]$ & Poland & $-1.47[-1.22]$ & $-0.45[-1.46]$ \\
\hline Estonia & $0.49[0.73]$ & $0.19[0.70]$ & Portugal & $-2.29[-0.79]$ & $-0.48[-0.85]$ \\
\hline Finland & $1.16[0.65]$ & $0.21[0.59]$ & Romania & $0.90[1.41]$ & $0.20[1.35]$ \\
\hline Georgia & $-1.03[-0.54]$ & $-0.24[-0.55]$ & Spain & $0.30[0.31]$ & 0.07 [0.37] \\
\hline Germany & $1.06[0.78]$ & $0.20[0.75]$ & Sudan & $2.64 * *[2.74]$ & $0.66^{* *}[2.61]$ \\
\hline Greece & $-1.83^{*}[-1.84]$ & $-0.37^{*}[-1.85]$ & Sweden & $-0.42[-0.52]$ & $-0.24[-0.96]$ \\
\hline Indonesia & 2.55 [1.19] & $-0.43[-0.84]$ & Switzerland & $1.21[0.76]$ & $0.26[0.74]$ \\
\hline Iran & $1.06^{* *}[2.81]$ & $-0.09[-1.01]$ & Tajikistan & $-0.50^{* *}[-2.21]$ & $-0.12^{* *}[-2.29]$ \\
\hline Ireland & $-2.40[-1.05]$ & $-0.49[-1.04]$ & Tunisia & $-0.20[-0.06]$ & $-0.04[-0.05]$ \\
\hline Israel & $0.07[0.03]$ & $0.00[0.00]$ & Turkey & - & $-0.08[-1.29]$ \\
\hline Italy & $-0.36[-0.34]$ & $-0.08[-0.40]$ & Turkmenistan & $0.34[0.26]$ & $0.04[0.14]$ \\
\hline Jordan & $-9.15[-1.68]$ & $-1.70[-1.64]$ & $\begin{array}{l}\text { United Arab } \\
\text { Emirates }\end{array}$ & $-2.38[-1.01]$ & $-0.68[-1.05]$ \\
\hline $\begin{array}{l}\text { Kyrgyz } \\
\text { Republic }\end{array}$ & $-0.18[-1.01]$ & $-0.31[-1.65]$ & $\begin{array}{l}\text { United } \\
\text { Kingdom }\end{array}$ & $-11.27[-1.33]$ & $-2.18[-1.32]$ \\
\hline Latvia & $0.17[0.11]$ & $0.02[0.07]$ & United States & $-0.39[-0.24]$ & $-0.10[-0.29]$ \\
\hline Lebanon & $1.97^{* * *}[4.52]$ & $-0.57^{* *}[-2.72]$ & Uzbekistan & $-0.62^{* *}[-2.77]$ & $-0.10^{* *}[-2.25]$ \\
\hline Libya & $-9.86[-0.76]$ & $-2.08[-0.76]$ & Venezuela & $-17.62[-0.85]$ & $-3.54[-0.87]$ \\
\hline Constant & $9.41^{* * *}[30.82]$ & & & & \\
\hline
\end{tabular}

Notes: Values in parentheses are $t$-statistics. Asterisks ${ }^{* * *},{ }^{* *}$, and ${ }^{*}$ denote statistical significance at the $1 \%, 5 \%$, and $10 \%$ levels, respectively. Values in boldface refer to significant results. Turkey is treated as the intercept country.

and Uzbekistan $(-11 \%)$ they garner negative price premiums. There are several export countries-namely, Australia, Canada, Germany, and Russia-that also sell wheat to Iran. However, because of its geographic advantages, Kazakhstan has the chance to strengthen its position in the Iranian wheat market and thus can charge a higher price markup.

Because of its political relations and geographic locations, Kazakhstan has the highest market share in wheat exports to Central Asian markets. Specifically, the average Kazakh market shares for the years 1996-2012 are 91\%, 95\%, 76\%, and $84 \%$, respectively, for the Kyrgyz Republic, Tajikistan, Turkmenistan, and Uzbekistan. However, PTM results show that Kazakh wheat exporters are in perfect competition in the Kyrgyz Republic and Turkmenistan but stabilize the export prices in Tajikistan and Uzbekistan in the case of the domestic currencies' depreciation. Additionally, even though Kazakhstan shares the 
Table 5. Pricing-to-Market Results for Russia

\begin{tabular}{|c|c|c|c|c|c|}
\hline \multicolumn{2}{|c|}{ Destinations $\lambda$} & \multirow{2}{*}{$\frac{\beta}{-1.26[-1.06]}$} & \multirow{2}{*}{$\begin{array}{l}\text { Destinations } \\
\text { Malaysia }\end{array}$} & \multirow{2}{*}{$\frac{\lambda}{0.55[0.44]}$} & \multirow{2}{*}{$\frac{\beta}{0.20[0.32]}$} \\
\hline Afghanistan & $1.15[1.36]$ & & & & \\
\hline Albania & $0.25[0.51]$ & $-0.14[-0.33]$ & Malta & $0.44[1.10]$ & $0.09[0.81]$ \\
\hline Algeria & $0.33[0.29]$ & $-0.40[-0.34]$ & Mauritania & $3.03[1.34]$ & $-1.28[-1.21]$ \\
\hline Armenia & $-0.79[-1.65]$ & $0.37^{* *}[2.36]$ & Moldova & $-0.17[-0.55]$ & $-0.98^{* *}[-2.20]$ \\
\hline Austria & $-0.15[-0.25]$ & $-0.04[-0.24]$ & Mongolia & $-0.98[-0.96]$ & $0.35[1.36]$ \\
\hline Azerbaijan & $0.74^{* *}[2.88]$ & $0.17^{*}[2.00]$ & Morocco & $0.29^{* *}[2.45]$ & $0.15^{* *}[2.71]$ \\
\hline Bangladesh & $-0.39[-1.10]$ & $0.49[1.45]$ & Mozambique & $0.18[0.95]$ & $0.28[0.72]$ \\
\hline $\begin{array}{l}\text { British } \\
\text { Virgin } \\
\text { Islands }\end{array}$ & $0.05[0.37]$ & $-0.03[-0.30]$ & Netherlands & $-0.68[-0.44]$ & $-0.18[-0.39]$ \\
\hline Bulgaria & $0.20[0.97]$ & $-0.03[-0.28]$ & Nigeria & $0.67[0.57]$ & $-0.47[-0.66]$ \\
\hline Cyprus & [2.24] & $0.16^{*}[1.7$ & North Kor & 75] & \\
\hline Denmark & {$[3.43]$} & $* *[2.97]$ & Norway & {$[-0.55]$} & $-0.37[-0.56]$ \\
\hline $\begin{array}{l}\text { Democratic } \\
\text { Republic } \\
\text { of Congo }\end{array}$ & $2.67^{* * *}[10.27]$ & $-0.79^{* * *}[-7.03]$ & ] Oman & $3.57^{* * *}[3.01]$ & $0.78^{* *}[2.72]$ \\
\hline Egypt & $0.37[1.12]$ & $0.16[0.85]$ & Pakistan & $-0.25[-0.89]$ & $0.47^{* * *}[6.03]$ \\
\hline Eritrea & $-0.01[-0.04]$ & -0.23 & Peru & $*[4.59]$ & $0.50^{* * *}[$ \\
\hline Estonia & 0.02 [0.17] & 0.06 & Poland & $0.13[0.78]$ & $-0.22 *[-1.86]$ \\
\hline Ethiopia & $0.33^{*}[1.81]$ & $0.42^{* * *}[3.64]$ & $\begin{array}{c}\text { Republic of } \\
\text { Yemen }\end{array}$ & $-0.66[-0.62]$ & $0.40[0.76]$ \\
\hline inland & $3.05^{* * *}[6.37]$ & $0.81^{* * *}[4.55]$ & Romania & & \\
\hline Georgia & $0.66[1.46]$ & 0.1 & Rwanda & 0.7 & $-0.22[-0.41]$ \\
\hline Germany & $4.07^{* *}[2.53]$ & $1.11^{* *}[2.48]$ & Saudi Arabia & $2.59^{* * *}[3.45]$ & $1.29^{* * *}[3.50]$ \\
\hline Greece & 1.05 [1.56] & $0.29[1.42]$ & South Ko & $0.07[0.15]$ & $-0.00[-0.01]$ \\
\hline Hungary & 1.33 [1.61] & $-0.49[-1.67]$ & Spain & $-1.19[-0.63]$ & $-0.32[-0.59]$ \\
\hline India & $-1.38^{*}[-2.02]$ & $3.06^{* *}[2.20]$ & Sudan & 0.49 [0.77] & $0.14[0.49]$ \\
\hline Indonesia & $1.51[0.46]$ & $-0.24[-0.44]$ & Sweden & $0.78^{* * *}[5.63]$ & $0.58^{* *}[2.57]$ \\
\hline Iran & $-2.07[-1.48]$ & $0.36[1.55]$ & Switzerland & $0.46^{*}[1.91]$ & $0.13[1.14]$ \\
\hline Iraq & $-0.74^{*}[-2.00]$ & $0.26[1.52]$ & $\begin{array}{c}\text { Syrian Arab } \\
\text { Republic }\end{array}$ & $-0.48[-1.26]$ & $-0.59[-1.47]$ \\
\hline srael & - & $-0.00[-0.02]$ & Tajikistan & & \\
\hline Italy & $-0.19[-0.29]$ & $-0.05[-0.31]$ & Tanzania & $1.62 *[1.96]$ & $-0.39[-1.47]$ \\
\hline Japan & $-1.32^{* * *}[-5.79]$ & $1.48^{* * *}[7.80]$ & Thailand & $-0.02[-0.12]$ & $0.28[0.80]$ \\
\hline ordan & $1.18[0.58]$ & $0.28[0.5$ & Tunisia & $2.54^{* * *}[22.27]$ & $0.78^{* * *}[14.59]$ \\
\hline Kenya & $0.40[0.77]$ & $-0.24[-0.47]$ & Turkey & 0.34 [0.63] & 0.08 [0.39] \\
\hline $\begin{array}{l}\text { Kyrgyz } \\
\text { Republic }\end{array}$ & $0.72[1.31]$ & $-0.32[-0.54]$ & Turkmenistan & $-1.10[-1.33]$ & $-0.82^{* *}[-2.83]$ \\
\hline Latvia & $-0.30[-0.41]$ & $-0.13[-0.66]$ & $\begin{array}{c}\text { United Arab } \\
\text { Emirates }\end{array}$ & $0.43[0.50]$ & $0.16[0.38]$ \\
\hline Lebanon & $-0.30[-0.84]$ & & Uganda & 1.13 & $-0.23[-0.4$ \\
\hline Libya & $0.95[0.61]$ & $0.29[0.57]$ & $\begin{array}{l}\text { United } \\
\text { Kingdom }\end{array}$ & $-6.42[-1.70]$ & $-1.76[-1.71]$ \\
\hline & $0.43^{*}[1.81]$ & 0.16 [1.32] & Uzbekistan & $1.12[1.3$ & $-0.14[-0.53]$ \\
\hline Constant & $8.07^{* * *}[50.04]$ & & Vietnam & $-0.53[-0.16]$ & $0.09[0.18]$ \\
\hline
\end{tabular}

Notes: Values in parentheses are $t$-statistics. Asterisks ${ }^{* * *},{ }^{* *}$, and ${ }^{*}$ denote statistical significance at the $1 \%, 5 \%$, and $10 \%$ levels, respectively. Values in boldface refer to significant results. Israel is treated as the intercept. 
Table 6. Pricing-to-Market Results for Ukraine

\begin{tabular}{|c|c|c|c|c|c|}
\hline \multicolumn{2}{|c|}{ Destinations $\lambda$} & \multirow{2}{*}{$\frac{\beta}{-0.08[-0.58]}$} & \multirow{2}{*}{$\begin{array}{l}\text { Destinations } \\
\text { Lithuania }\end{array}$} & \multirow{2}{*}{$\begin{array}{l}\lambda \\
0.31^{*}[1.84]\end{array}$} & \multirow{2}{*}{$\frac{\beta}{0.02[0.12]}$} \\
\hline Albania & $0.78[1.42]$ & & & & \\
\hline Algeria & $-0.13[-0.24]$ & $0.18^{*}[1.89]$ & Malaysia & $0.07[0.88]$ & $-0.10[-0.99]$ \\
\hline Armenia & $0.57[0.84]$ & $0.06[0.65]$ & Mauritania & $1.96^{* *}[2.17]$ & $-0.40^{* *}[-2.33]$ \\
\hline Austria & $-0.02[-0.10]$ & $0.05[0.95]$ & Moldova & $1.52^{* * *}[3.54]$ & $-0.96^{*}[-1.78]$ \\
\hline Azerbaijan & $0.14[0.50]$ & $0.10[0.73]$ & Morocco & $0.19 *[1.82]$ & $-0.02[-0.52]$ \\
\hline Bangladesh & $0.61[1.24]$ & $-0.10[-0.90]$ & Myanmar & $0.24^{* * *}[3.09]$ & $-0.54^{* *}[-2.21]$ \\
\hline Belarus & $-0.35[-0.78]$ & $0.22[1.36]$ & Netherlands & $-0.02[-0.06]$ & $0.01[0.06]$ \\
\hline Belgium & $0.39^{*}[1.91]$ & $0.34^{* * *}[3.00]$ & Nigeria & $-0.43[-0.33]$ & $0.24[0.70]$ \\
\hline Bermuda & $-0.12[-0.84]$ & $-0.01[-0.10]$ & North Korea & $0.06[0.60]$ & $0.13[0.78]$ \\
\hline $\begin{array}{l}\text { British } \\
\text { Virgin } \\
\text { Islands }\end{array}$ & $-0.11[-0.53]$ & $-0.02[-0.15]$ & Peru & $-0.59[-0.78]$ & $-1.68[-0.93]$ \\
\hline Bulgaria & $0.81^{* * *}[3.56]$ & $0.43^{*}[1.89]$ & Philippines & $0.01[0.02]$ & $0.10[0.87]$ \\
\hline Cyprus & $-0.22[-0.85]$ & $0.00[0.04]$ & Poland & $0.16^{* *}[2.30]$ & $-0.14^{*}[-2.03]$ \\
\hline Djibouti & $2.29^{* * *}[3.20]$ & $-0.54^{* *}[-2.22]$ & Portugal & $-0.46^{* *}[-2.26]$ & $-0.10[-1.10]$ \\
\hline Egypt & $0.09^{* *}[2.29]$ & $-0.34^{* * *}[-3.01]$ & $\begin{array}{l}\text { Republic of } \\
\text { Yemen }\end{array}$ & $0.94[0.68]$ & $-0.10[-0.35]$ \\
\hline Eritrea & $1.06^{* * *}[3.87]$ & $-0.85^{*}[-2.05]$ & Saudi Arabia & $0.26^{*}[1.89]$ & $0.24[0.81]$ \\
\hline Estonia & $-0.22[-0.77]$ & $0.35^{*}[2.10]$ & $\begin{array}{l}\text { Slovak } \\
\text { Republic }\end{array}$ & $0.24[0.46]$ & $0.09[0.49]$ \\
\hline France & $-0.28[-1.04]$ & $-0.09[-0.74]$ & South Africa & $0.19[1.70]$ & $-0.03[-0.14]$ \\
\hline Georgia & $0.20[1.05]$ & $0.02[0.16]$ & South Korea & $0.31[0.35]$ & $0.07[0.76]$ \\
\hline Germany & $0.22[0.70]$ & $0.18[1.72]$ & Spain & $-0.42^{* *}[-2.18]$ & $-0.10[-1.11]$ \\
\hline Greece & $-0.45^{* *}[-2.27]$ & $-0.18^{* *}[-2.48]$ & Sri Lanka & $-1.34[-0.55]$ & $0.69[0.75]$ \\
\hline Hungary & $0.14[0.23]$ & $0.10[1.05]$ & Sudan & $-0.07[-0.38]$ & $-0.16[-0.83]$ \\
\hline India & $0.55[0.92]$ & $-0.08[-0.50]$ & Switzerland & $-0.29[-1.55]$ & $-0.24^{* *}[-2.51]$ \\
\hline Indonesia & $2.61 *[1.83]$ & $-0.22[-1.43]$ & $\begin{array}{c}\text { Syrian Arab } \\
\text { Republic }\end{array}$ & $0.23[1.63]$ & $-0.06[-0.45]$ \\
\hline Iraq & 0.55 [0.87] & $0.04[0.47]$ & Tajikistan & 0.38 [1.73] & $0.09[0.29]$ \\
\hline Ireland & $-0.17[-0.70]$ & $-0.13[-0.74]$ & Thailand & $-1.66^{* *}[-2.55]$ & $1.40^{* *}[2.92]$ \\
\hline Israel & - & $-0.12[-0.97]$ & Tunisia & $-0.00[-0.00]$ & $0.02[0.20]$ \\
\hline Italy & $-0.14[-0.73]$ & $0.05[0.78]$ & Turkey & $0.77[1.46]$ & 0.39 [1.12] \\
\hline Jordan & $0.37[0.66]$ & $0.20[0.99]$ & Uganda & $2.69[1.13]$ & $-0.31[-0.93]$ \\
\hline Kenya & $1.21[1.73]$ & $-0.29[-1.61]$ & $\begin{array}{c}\text { United Arab } \\
\text { Emirates }\end{array}$ & $0.02[0.23]$ & $-0.06[-0.37]$ \\
\hline Latvia & $0.55[1.33]$ & $0.36^{*}[2.10]$ & $\begin{array}{l}\text { United } \\
\text { Kingdom }\end{array}$ & $-0.17[-0.58]$ & $-0.00[-0.11]$ \\
\hline Lebanon & $0.74[1.12]$ & $0.03[0.50]$ & United States & $0.02[0.05]$ & $0.13[0.85]$ \\
\hline Libya & $-0.64^{* *}[-2.57]$ & $-0.32^{* *}[-2.19]$ & Uzbekistan & $1.45^{* * *}[3.20]$ & $0.44 *[1.94]$ \\
\hline Constant & $6.44^{* * *}[182.14]$ & & Vietnam & $2.57[0.99]$ & $-0.18[-0.81]$ \\
\hline
\end{tabular}

Notes: Values in parentheses are $t$-statistics. Asterisks ${ }^{* * *},{ }^{* *}$, and ${ }^{*}$ denote statistical significance at the $1 \%, 5 \%$, and $10 \%$ levels, respectively. Values in boldface refer to significant results. Israel is treated as an intercept country. 
Azerbaijani wheat market only with Russia, it cannot price discriminate in this market.

The quantities that Kazakhstan exports to Albania, Lebanon, Lithuania, and Sudan are very small (i.e., they are small buyers), and they do not trade regularly with Kazakhstan. Additionally, Lithuania is a wheat producing and exporting country. Therefore, the PTM results for those countries might not reflect reality. Since 2004, Greece has regularly imported wheat from Kazakhstan in small quantities. There are several wheat exporters (mainly EU countries) in the Greek import market; however, Kazakh wheat exporters exercise price discrimination and enjoy a price premium $(24 \%)$ in Greece.

The PTM results for Russia show that Russian wheat exporters use PTM in 20 out of 71 destinations (see Table 5). In contrast to the results for Kazakhstan, in most importing countries Russian exporters amplify the effect of destinationspecific exchange rate changes by changing the destination-specific markup (significantly positive $\beta$ )-namely, Armenia, Azerbaijan, Cyprus, Denmark, Ethiopia, Finland, Germany, India, Japan, Morocco, Oman, Pakistan, Peru, Saudi Arabia, Sweden, and Tunisia.

However, Russian exporters stabilize the local currency prices in the Democratic Republic of the Congo, Moldova, Poland, and Turkmenistan. Russian wheat exporters price discriminate with constant markup in Iraq, Lithuania, North Korea, Romania, Switzerland, and Tanzania; that is, they charge higher price markups than Israel (intercept country) in those destinations. However, the evidence of price discrimination by Russian exporters is not observed in the 45 other importing countries. The reason is that Russia usually exports an undifferentiated quality of wheat to the world market and thus cannot compete with the traditional wheat exporters in most destinations (Pall et al., 2013).

Just as in the case of Kazakhstan, some PTM results should be carefully interpreted. According to United Nations Commodity Trade Statistics Database (UN Comtrade, 2015) statistics, Armenia, Azerbaijan, Iraq, Morocco, and Tunisia are consistent markets for Russian exporters. These countries regularly trade with Russia and usually import wheat in large quantities. Armenia mainly imports wheat from Russia, and Azerbaijan from Kazakhstan and Russia. Therefore, Russian exporters use PTM behavior in Armenia and Azerbaijan, and enjoy $24 \%$ and $14 \%$ price premiums, respectively.

Russia competes with Australia, Canada, Turkey, and other wheat exporters in the Iraqi wheat market, and because of its greater potential and geographic advantages, has the chance to improve its position in this market. Perhaps using PTM in the Iraqi wheat market is why Russia enjoys a $35 \%$ price premium.

Several countries including Canada, Russia, the USA, and Ukraine, as well as the EU, export wheat to the Moroccan and Tunisian wheat markets. However, Russian wheat exporters exercise price discrimination and garner price premium in these markets (Morocco, 132\%; Tunisia, 30\%). Similarly, Russian exporters 
compete with some EU countries in the Cypriot wheat market with $16 \%$ average market share for the years 1996-2012. Therefore, they use PTM behavior and enjoy a $16 \%$ price premium in this market. In the Omani wheat market, Russia competes with Argentina, Australia, and India. Even though its average market share in this market from 1996-2012 is only 11\%, Russia garners an even higher price premium $(85 \%)$. According to Table 5, Russia does not price discriminate in the Egyptian wheat market. This was expected, because, as the largest wheat buyer in the world, Egypt imports wheat from many different sources, including Australia, Canada, France, Russia, Ukraine, and the USA. Therefore, if there is an increase in wheat export price charged by the Russian exporters, Egypt will simply decrease its wheat import quantity from Russia and increase imports from other exporters.

The results for Denmark, Germany, India, Lithuania, Pakistan, Poland, Romania, and Sweden should be carefully interpreted because they are wheat producing and exporting countries. Moreover, the Democratic Republic of the Congo, Ethiopia, Finland, Japan, North Korea, Peru, and Turkmenistan are not consistent markets for Russia, and they do not regularly import wheat from Russia. Therefore, the results that show price discrimination in those countries might not express reality.

Because of its geographic location, Ukrainian wheat exporters use PTM behavior in 17 importing countries, primarily the EU and MENA countries (see Table 6).

Similar to Kazakhstan, in most countries-Djibouti, Egypt, Eritrea, Greece, Libya, Mauritania, Moldova, Myanmar, Poland, and Switzerland-Ukrainian exporters stabilize the local currency prices. However, they amplify the effect of destination-specific exchange rate changes in Algeria, Belgium, Bulgaria, Estonia, Latvia, Thailand, and Uzbekistan. Additionally, Ukrainian wheat exporters price discriminate with constant markup in Indonesia, Lithuania, Morocco, Portugal, Saudi Arabia, and Spain, which means they charge higher markups in these destinations than Israel (intercept country).

Price discrimination is not observed in the 42 other importing countries. The main reason is that Ukraine usually exports feed wheat to the world market (Kobuta, Sikachyna, and Zhygadlo, 2012), and there are many substitutes for it.

Algeria, Egypt, Greece, Indonesia, Libya, Mauritania, Moldova, Morocco, Spain, and Switzerland are consistent markets for Ukrainian wheat exporters. Except for Indonesia, all countries are either EU or North African countries. North African countries-Algeria, Egypt, Libya, Mauritania, and Moroccousually import wheat from various sources, such as Canada, the EU, the USA, Russia, and Ukraine. However, because of its geographic location, Ukraine has the chance to price discriminate in these markets and therefore garners positive price premiums (Algeria, 8\%; Egypt, 33\%; Libya, 42\%; Mauritania, $18 \%$; and Morocco, 17\%). Moldova is a landlocked country and usually prefers to import from neighboring countries-namely, Romania and Ukraine, as well 
Table 7. Statistical Inference of Estimated Pricing-to-Market Models

\begin{tabular}{lccc}
\hline \hline & Kazakhstan & Russia & Ukraine \\
\hline Number of observations & 451 & 660 & 605 \\
Number of time series & 17 & 17 & 17 \\
Number of cross sections & 48 & 71 & 65 \\
$R$-squared & 0.30 & 0.65 & 0.50 \\
Akaike information criterion & 313.60 & -48.93 & -352.34 \\
Bayesian information criterion & 379.39 & 22.94 & -281.86 \\
\hline \hline
\end{tabular}

as Russia. Recent United Nations Commodity Trade Statistics Database (UN Comtrade, 2015) statistics show that Moldova has increased its wheat imports from Ukraine. Therefore, Ukrainian exporters do price discriminate and enjoy a $132 \%$ price premium in the Moldavian wheat market. Australia, Canada, and the USA are important players in the Indonesian wheat market, and the Ukrainian market share is very tiny. However, PTM results demonstrate that Ukrainian exporters exercise price discrimination in the Indonesian wheat market and enjoy a $46 \%$ price premium.

Because Belgium, Bulgaria, Greece, Latvia, Lithuania, Poland, and Spain are simultaneously wheat producing and exporting countries, the PTM results for those countries do not demonstrate that Ukrainian wheat exporters use pricing behavior to price discriminate in these markets. Moreover, Switzerland imports wheat mainly from the EU, but the results show that Ukraine exercises price discrimination in the Swiss wheat market. Djibouti, Eritrea, Myanmar, Portugal, Saudi Arabia, Thailand, and Uzbekistan do not trade with Ukraine regularly, and thus a conclusion cannot be drawn from these results.

The statistical inferences of the PTM models are listed in Table 7. The number of observations is different for each data set. The Russian data set contains trade statistics for the most importing countries (number of cross sections) and logically also has the maximum number of observations.

However, the time series are the same because all data sets cover the period 1996-2012. The $R$-squared values between observed and predicted values are 0.30, 0.65, and 0.50, respectively, for Kazakhstan, Russia, and Ukraine. Additionally, the results for Akaike information criterion and Bayesian information criterion demonstrate that the PTM model for Russia achieves better performance than the PTM models for Ukraine and Kazakhstan.

\section{Conclusion and Policy Implications}

Because of the restructuring policies in agricultural production, consumption, and trade sectors during the 1990s, as well as a massive increase in wheat production during the 2000s, Black Sea region wheat exporters became important players in the world market during the early 2000s. 
We analyze the changes in pricing behavior of KRU exporters in response to the bilateral exchange rate fluctuations. Specifically, we investigate whether KRU countries are able to price discriminate in selected importing markets during the period 1996-2012. The results of this research indicate that Kazakhstan and Ukraine stabilize local currency prices in most wheat importing countries, whereas Russia amplifies the effect of destination-specific exchange rate changes.

Because of political relations and geographic locations, the main destinations for KRU exporters are South Caucasus, Central Asia, and some EU and MENA countries. Although Kazakhstan is a leading wheat exporting country in Central Asia, it is able to use PTM behavior only in Tajikistan and Uzbekistan. Moreover, even though all KRU countries are active wheat exporters to the South Caucasian countries, only Russia is able to exercise price discrimination in the Armenian and Azerbaijani wheat markets. Kazakhstan and Ukraine face perfect competition in all three countries in this region. As the Georgian government implements a diversification policy on wheat imports and buys wheat from multiple sources (KRU, Germany, Israel, Italy, Romania, Turkey, and the USA), despite their high market shares, none of the KRU countries can exercise price discrimination in this market. Ukraine is able to export and exercise price discrimination in some EU and MENA countries because of its geographic advantages.

The results of this study contradict the ones by Pall et al. (2013), who investigated the PTM behavior of Russian exporters in 25 destinations. These authors found that Russia amplifies the effect of destination-specific exchange rate changes in Algeria and India but stabilizes local currency prices in Azerbaijan, Cyprus, and Mongolia over the period 2002-2010. Only the conclusion for India is in line with our results.

Kazakhstan and Russia do not price discriminate in the Egyptian wheat market, whereas Ukraine stabilizes the wheat export prices in Egyptian pounds. These results were expected because Egypt is the largest wheat importer in the world and usually imports from multiple sources (e.g., Argentina, Canada, EU, Russia, Ukraine, and the USA). This situation gives Egypt monopsony power, and in order to maintain their market share, exporters are sensitive to the changes in export prices of wheat in this country.

According to the PTM results, in only $17 \%$ of total destinations can Kazakhstan exercise price discrimination, whereas Russia can do so in $37 \%$ and Ukraine in $35 \%$; in most destination countries, KRU countries cannot exercise PTM behavior.

There are three main reasons why KRU countries cannot price discriminate in their export destinations: (1) their production is highly weather dependent; (2) they mainly export an undifferentiated quality of wheat, or feed wheat; and (3) they periodically implement export restriction policies. Because of their weather-dependent production, they are not able to trade regularly with their main partners. Therefore, importing countries switch to buy wheat from more reliable sources. Compared with the traditional wheat exporters, KRU countries 
usually have short-term relations with their partner countries (mainly developing countries). Moreover, Russia chiefly exports an undifferentiated quality of wheat, whereas Ukraine is specialized in feed wheat exports. This makes the competition tougher for both of them because the demand is highly elastic for their products, and there are many competitors in the market that offer substitutes (Pall et al., 2013). Hence, most importing countries can easily switch to import wheat from other exporters if KRU countries increase wheat export prices. However, despite having higher protein-content wheat than Russia and Ukraine, Kazakhstan is not able to price discriminate in most destinations, as it is geographically distant from most export destinations.

Moreover, several trade restriction policies have been implemented by KRU countries since 2007, with the most recent being implemented by the Russian government on February 1, 2015. ${ }^{11}$ These policies disrupt their wheat trade with most export destinations. For example, when Ukraine set export restrictions in 2007, its main importing countries-Egypt, Israel, Italy, Tunisia, and Yemenimported more from Kazakhstan and Russia (Dollive, 2008). Export restrictions isolate KRU countries from the global wheat market, which reduces the global wheat supply and affects global food security. These reasons cause KRU countries to be branded as unreliable wheat exporters in the world wheat market.

In order to strengthen their reputation in the world market, it would benefit KRU countries to abstain from setting any restriction policies on wheat. This would improve their relations with importing countries and reduce disruptions in wheat exports.

Future research should incorporate the pricing behavior of the KRU countries using firm-level data. This would render a much clearer picture of the competitive structure of the wheat market.

\section{References}

Baltagi, B.H. Econometric Analysis of Panel Data. 3rd ed. Chichester, UK: Wiley, 2005.

Brown, J. "Price Discrimination and Pricing to Market Behavior of Canadian Canola Exporters.” American Journal of Agricultural Economics 83(2001):1343-49.

Carew, R. "Pricing to Market Behavior: Evidence from Selected Canadian and U.S. Agri-Food Exports." Journal of Agricultural and Resource Economics 25(2000):578-95.

Carew, R., and W.J. Florkowski. "Pricing to Market Behavior by Canadian and U.S. Agri-Food Exporters: Evidence from Wheat, Pulse and Apples." Canadian Journal of Agricultural Economics 51(2003):139-59.

Dollive, K. "The Impact of Export Restraints on Rising Grain Prices." Working paper no. 2008-09-A, Washington, DC: U.S. International Trade Commission, 2008.

Falk, M., and R. Falk. "Pricing to Market of German Exporters: Evidence from Panel Data." Empirica 27(2000):21-46.

FAOSTAT, Food and Agriculture Organization of the United Nations. Statistics Division. Internet site: http://faostat.fao.org/ (Accessed June 15, 2015).

11 Government of the Russian Federation, Resolution No. 1495 (Russian Government, 2014). 
Fedoseeva, S. “(A)symmetry, (Non)linearity and Hysteresis of Pricing-to-Market: Evidence from German Sugar Confectionary Exports.” Journal of Agricultural \& Food Industrial Organization 11(2013):69-85.

FAO/EBRD, Food and Agriculture Organization of the United Nations [FAO]/European Bank for Reconstruction and Development [EBRD]. Ukraine: Grain Sector Review and Public Private Policy Dialogue. Report Series No. 15, December 2010. Internet site: http://www.fao.org/docrep/018/i3337e/i3337e.pdf (Accessed February 11, 2015).

Gil-Pareja, S. "Export Price Discrimination in Europe and Exchange Rates." Review of International Economics 10(2002):299-312.

Glauben, T., and J.-P. Loy. "Pricing-to-Market versus Residual Demand Elasticity Analysis of Imperfect Competition in Food Exports: Evidence from Germany.” Journal of Agricultural \& Food Industrial Organization 1 (2003):1-19.

Götz, L., T. Glauben, and B. Brümmer. "Wheat Export Restrictions and Domestic Market Effects in Russia and Ukraine during the Food Crisis." Food Policy 38(2013):21426.

Griffith, G., and J. Mullen. "Pricing-to-Market in NSW Rice Export Markets." Australian Journal of Agricultural and Resource Economics 45(2001):32334.

IMF, International Monetary Fund. Internet site: http://www.imf.org (Accessed June 11, 2015).

Jin, H. "Competitive Structure of Canadian Wheat Exports in the World Market." Applied Economics Letters 15(2008):1059-64.

Jin, H., and D. Miljkovic. "Competitive Structure of U.S. Grain Exporters in the World Market: A Dynamic Panel Approach.” Journal of International Economic Studies 12(2008):33-63.

Kim, J. "Recent Trends in Export Restrictions." Organization for Economic Cooperation and Development (OECD) Trade Policy Papers, No. 101, Paris: OECD, 2010.

Knetter, M.M. "Price Discrimination by U.S. and German Exporters." American Economic Review 79(1989):198-210.

Knetter, M.M. "International Comparisons of Pricing-to-Market Behavior." American Economic Review 83(1993):473-86.

Knetter, M.M. "Pricing to Market in Response to Unobservable and Observable Shocks." International Economic Journal 9(1995):1-25.

Kobuta, I., O. Sikachyna, and V. Zhygadlo. Wheat Export Economy in Ukraine. Budapest: Food and Agriculture Organization of the United Nations, Regional Office for Europe and Central Asia, Policy Studies on Rural Transition No. 2012-4, July 2012.

Krugman, P. "Pricing to Market When Exchange Rate Changes." Real-Financial Linkages among Open Economies. S.W. Arndt and J.D. Richardson, eds. Cambridge, MA: MIT Press, 1987.

Lavoie, N., and Q. Liu. "Pricing-to-Market: Price Discrimination or Product Differentiation?" American Journal of Agricultural Economics 89(2007):571-81.

Liefert, O., W. Liefert, and E. Luebehusen. Rising Grain Exports by the Former Soviet Union Region: Causes and Outlook. Washington, DC: U.S. Department of Agriculture, Economic Research Service, Outlook WHS-13A-01, February 2013.

OANDA, Online Forex Trading and Currency Services. Internet site: http://www.oanda.com (Accessed June 11, 2015). 
OECD/FAO, Organization for Economic Cooperation and Development/Food and Agriculture Organization for the United Nations. OECD-FAO Agricultural Outlook 2014. OECD Publishing. Internet site: http://dx.doi.org/10.1787/agr_outlook-2014-en (Accessed June 11, 2015).

Pall, Z., O. Perekhozhuk, R. Teuber, and T. Glauben. "Are Russian Wheat Exporters Able to Price Discriminate? Empirical Evidence from the Last Decade.” Journal of Agricultural Economics 64(2013):177-96.

Pick, D.H., and C.A. Carter. "Pricing to Market with Transactions Denominated in a Common Currency." American Journal of Agricultural Economics 76(1994):5560 .

Pick, D.H., and T.A. Park. "The Competitive Structure of U.S. Agricultural Exports." American Journal of Agricultural Economics 73(1991):133-41.

ROSSTAT, Russian Federation Federal State Statistics Service. Russian Statistical Yearbook: Statistical Handbook. Moscow: ROSSTAT, 2001, 2007, 2013.

Russian Government. "Government Decisions: Introduction of Grain Export Duty and Setting the Tax Rate.” December 25, 2014. Internet site: http://government.ru/en/docs/16329/ (Accessed March 21, 2015).

Tothova, M., W.H. Meyers, and K. Goychuk. "Productivity Growth and Variability in KRU: Evidence and Prospects." Paper presented at the Public Trade Policy Research and Analysis Symposium "Productivity and Its impacts on Global Trade," Seville, Spain, June 2-4, 2013.

United Nations. UN Comtrade Statistics Database. Internet site: http://comtrade.un.org/ (Accessed January 15, 2015).

United Nations, Department of Economic and Social Affairs, Statistics Division. "International Merchandise Trade Statistics: Concepts and Definitions 2010." Statistical Papers, Series M, No. 52, New York: United Nations, 2011.

U.S. Department of Agriculture (USDA). USDA Agricultural Projections to 2023. Prepared by the Interagency Agricultural Projections Committee. Washington, DC: Office of the Chief Economist, World Agricultural Outlook Board, USDA, Long-term Projections Report OCE-2014-1, February 2014.

Wooldridge, J.M. Econometric Analysis of Cross Section and Panel Data. Cambridge, MA: MIT Press, 2002.

Yumkella, K.K., L.J. Unnevehr, and P. Garcia. "Noncompetitive Pricing and Exchange Rate Pass-Through in Selected U.S. and Thai Rice Markets.” Journal of Agricultural and Applied Economics 26(1994):404-16. 


\section{Appendix}

Table A1. Selected Studies Applying Pricing-to-Market Models

\begin{tabular}{|c|c|c|c|c|c|c|c|c|}
\hline Authors & $\begin{array}{l}\text { Journal }^{\mathrm{a}} \\
\text { (year) }\end{array}$ & Exporter & $\begin{array}{l}\text { (Number of) } \\
\text { Importers }\end{array}$ & $\begin{array}{l}\text { (Number of) } \\
\text { Product }\end{array}$ & Period & Data $^{b}$ & $\begin{array}{l}\text { Method/ } \\
\text { Estimator }^{\mathrm{c}}\end{array}$ & Result $^{\mathrm{d}}$ \\
\hline Knetter & AER (1989) & $\begin{array}{l}\text { United States } \\
\text { Germany }\end{array}$ & $\begin{array}{l}14 \\
10\end{array}$ & $\begin{array}{l}6 \\
10\end{array}$ & $\begin{array}{l}1978-1986 \\
1977-1985\end{array}$ & Q & FE & $\begin{array}{l}\text { AER: 11/46; LCPS: } 9 / 46 \\
\text { AER: 10/34; LCPS: } 24 / 34\end{array}$ \\
\hline Pick and Park & AJAE (1991) & United States & $\begin{array}{l}8 \\
10 \\
12 \\
10 \\
6\end{array}$ & $\begin{array}{l}\text { Wheat } \\
\text { Corn } \\
\text { Cotton } \\
\text { Soybeans } \\
\text { Soybean meal }\end{array}$ & 1978-1988 & Q & $\mathrm{FE}$ & $\begin{array}{l}\text { AER: } 2 / 8 \text {; CED: } 5 / 8 \text {; LCPS: } 1 / 8 \\
\text { CED: } 1 / 10 \text {; LCPS: } 1 / 10 \\
\text { LCPS: } 1 / 12 \\
\text { CED: } 1 / 10 \text {; LCPS: } 1 / 10 \\
\text { AER: } 2 / 6 \text {; CED: } 2 / 6\end{array}$ \\
\hline Knetter & AER (1993) & $\begin{array}{l}\text { United States } \\
\text { United } \\
\quad \text { Kingdom } \\
\text { Germany } \\
\text { Japan }\end{array}$ & & $\begin{array}{l}11 \\
9 \\
18 \\
14\end{array}$ & $\begin{array}{l}1973-1987 \\
1974-1987 \\
1975-1987 \\
1973-1987\end{array}$ & A & $\mathrm{n} / \mathrm{a}$ & $\begin{array}{l}\text { AER: } 2 / 11 \text {; LCPS: } 1 / 11 \\
\text { LCPS: } 2 / 9 \\
\text { LCPS: } 9 / 18 \\
\text { LCPS: } 8 / 14\end{array}$ \\
\hline $\begin{array}{r}\text { Pick and } \\
\text { Carter }\end{array}$ & AJAE (1994) & $\begin{array}{l}\text { United States } \\
\text { Canada }\end{array}$ & $\begin{array}{l}8 \\
3\end{array}$ & Wheat & 1978-1988 & Q & $\mathrm{FE}$ & $\begin{array}{l}\text { AER: } 2 / 8 \text {; CED: } 4 / 8 \text {; LCPS: } 3 / 8 \\
\text { AER: } 1 / 3 \text {; CED: } 1 / 3 \text {; LCPS: } 2 / 3\end{array}$ \\
\hline $\begin{array}{l}\text { Yumkella, } \\
\text { Unnevehr, } \\
\text { and Garcia }\end{array}$ & JAAE (1994) & Thailand & $\begin{array}{l}4 \\
5 \\
4\end{array}$ & $\begin{array}{l}\text { Parboil rice } \\
\text { Long grain } \\
\text { rice } \\
\text { Long grain } \\
\quad \text { rice }\end{array}$ & 1980-1987 & Q & GLS & $\begin{array}{l}\text { AER: } 1 / 4 \text {; CED: } 3 / 4 \\
\text { AER: } 2 / 5 \text {; CED: } 2 / 5 \\
\text { AER: } 1 / 4 \text {; CED: } 1 / 4\end{array}$ \\
\hline Knetter & IEJ (1995) & United States & 8 & 7 & 1973-1987 & A & $\mathrm{n} / \mathrm{a}$ & $\begin{array}{l}\text { AER: United Kingdom; LCPS: Canada, } \\
\text { France, Japan, Sweden, United States, } \\
\text { and United Kingdom } \\
\text { ARE: Australia, Canada, Italy, Japan, and } \\
\text { United Kingdom; LCPS: Australia, } \\
\text { Canada, Germany, Italy, Japan, Sweden, } \\
\text { and United Kingdom }\end{array}$ \\
\hline
\end{tabular}


Table A1. Continued

\begin{tabular}{|c|c|c|c|c|c|c|c|c|}
\hline Authors & $\begin{array}{l}J^{J o u r n a l}{ }^{a} \\
\text { (year) }\end{array}$ & Exporter & $\begin{array}{l}\text { (Number of) } \\
\text { Importers }\end{array}$ & $\begin{array}{l}\text { (Number of) } \\
\text { Product }\end{array}$ & Period & Data $^{b}$ & $\begin{array}{l}\text { Method/ } \\
\text { Estimator }^{\mathrm{c}}\end{array}$ & Result $^{\mathrm{d}}$ \\
\hline \multirow[t]{6}{*}{ Carew } & \multirow[t]{6}{*}{ JARE (2000) } & \multirow[t]{3}{*}{ Canada } & 9 & Wheat & \multirow[t]{3}{*}{ 1980-1994 } & \multirow[t]{3}{*}{ A } & \multirow[t]{3}{*}{ FE } & AER: 4/9; CED: 4/9 \\
\hline & & & 11 & Pulse & & & & AER: $3 / 11$; CED: $3 / 11$; LCPS: $1 / 11$ \\
\hline & & & 9 & Tobacco & & & & AER: $4 / 9 ;$ LCPS: $3 / 9$ \\
\hline & & \multirow[t]{3}{*}{ United States } & 13 & Wheat & \multirow[t]{3}{*}{ 1980-1994 } & \multirow[t]{3}{*}{ A } & \multirow[t]{3}{*}{ FE } & CED: 6/13; LCPS: 7/13 \\
\hline & & & 9 & Pulse & & & & CED: $4 / 9 ;$ LCPS: $4 / 9$ \\
\hline & & & 15 & Tobacco & & & & AER: 2/15; CED: 9/15; LCPS: 1/15 \\
\hline \multirow[t]{5}{*}{ Falk and Falk } & \multirow[t]{5}{*}{ E (2000) } & \multirow[t]{5}{*}{ Germany } & 15 & \multirow{5}{*}{70} & \multirow[t]{5}{*}{ 1990-1994 } & \multirow[t]{5}{*}{ A } & GMM & AER: 8/15 \\
\hline & & & 15 & & & & FE & LCPS: 6/15 \\
\hline & & & 15 & & & & LAD & AER: $1 / 15$; LCPS: 4/15 \\
\hline & & & 15 & & & & OLS & AER: $1 / 15$; LCPS: 4/15 \\
\hline & & & 9 & & & & $\mathrm{RCM}$ & LCPS: $5 / 15$ \\
\hline \multirow[t]{3}{*}{ Brown } & \multirow[t]{3}{*}{ AJAE (2001) } & \multirow[t]{3}{*}{ Canada } & Japan & \multirow[t]{3}{*}{ Canola } & 1993-1996 & \multirow[t]{3}{*}{ Q } & \multirow[t]{3}{*}{ GLS } & CED in all; LCPS in Japan \\
\hline & & & Mexico & & 1996-1999 & & & $\begin{array}{l}\text { CED in Japan and United States; } \\
\text { LCPS in all }\end{array}$ \\
\hline & & & United States & & 1993-1999 & & & CED in all; LCPS in Japan \\
\hline $\begin{array}{l}\text { Griffith and } \\
\text { Mullen }\end{array}$ & $\begin{array}{l}\text { AJARE } \\
(2001)\end{array}$ & Australia & 4 & Rice & 1982-1995 & M & OLS & AER: 1/4; CED: 2/4; LCPS: $1 / 4$ \\
\hline \multirow[t]{7}{*}{ Gil-Pareja } & \multirow[t]{7}{*}{ RIE (2002) } & $\begin{array}{l}\text { Belgium- } \\
\text { Luxembourg }\end{array}$ & $\begin{array}{l}\text { Organization } \\
\text { for }\end{array}$ & 17 & \multirow[t]{7}{*}{ 1988-1996 } & \multirow[t]{7}{*}{ Q } & \multirow[t]{7}{*}{ FE } & AER: $8 / 17$ \\
\hline & & France & Economic & 21 & & & & AER: $11 / 21$ \\
\hline & & Germany & $\begin{array}{l}\text { Cooperation } \\
\text { and }\end{array}$ & 19 & & & & AER: $12 / 19$ \\
\hline & & Italy & Development & 17 & & & & AER: $10 / 17$ \\
\hline & & Netherlands & countries & 10 & & & & AER: 4/10 \\
\hline & & Spain & & 15 & & & & AER: $7 / 15$ \\
\hline & & $\begin{array}{l}\text { United } \\
\text { Kingdom }\end{array}$ & & 16 & & & & AER: 1/16; LCPS: 1/16 \\
\hline
\end{tabular}


Table A1. Continued

\begin{tabular}{|c|c|c|c|c|c|c|c|c|}
\hline Authors & $\begin{array}{l}\text { Journal }^{\mathrm{a}} \\
\text { (year) }\end{array}$ & Exporter & $\begin{array}{l}\text { (Number of) } \\
\text { Importers }\end{array}$ & $\begin{array}{l}\text { (Number of) } \\
\text { Product }\end{array}$ & Period & Data $^{b}$ & $\begin{array}{l}\text { Method/ } \\
\text { Estimator }\end{array}$ & Result $^{\mathrm{d}}$ \\
\hline $\begin{array}{l}\text { Carew and } \\
\text { Florkowski }\end{array}$ & CJAE (2003) & United States & $\begin{array}{l}15 \\
13 \\
15 \\
15 \\
13 \\
15\end{array}$ & $\begin{array}{l}\text { Wheat } \\
\text { Pulse } \\
\text { Apple } \\
\text { Wheat } \\
\text { Pulse } \\
\text { Apple }\end{array}$ & 1980-1998 & A & $\mathrm{FE}$ & $\begin{array}{l}\text { AER: 4/15; CED: 5/15; LCPS: } 1 / 15 \\
\text { AER: 4/13; CED: 7/13; LCPS: } 1 / 13 \\
\text { CED: 3/15; LCPS: } 2 / 15 \\
\text { AER: } 1 / 15 \text {; CED: } 4 / 15 \text {; LCPS: } 9 / 15 \\
\text { CED: } 3 / 13 \text {; LCPS: } 5 / 13 \\
\text { CED: } 9 / 15 \text {; LCPS: } 9 / 15\end{array}$ \\
\hline $\begin{array}{l}\text { Glauben and } \\
\text { Loy }\end{array}$ & $\begin{array}{l}\text { JAFIO } \\
\quad(2003)\end{array}$ & Germany & $\begin{array}{l}\text { Canada, } \\
\text { United } \\
\text { States, } \\
\text { France, } \\
\text { United } \\
\text { Kingdom, } \\
\text { Belgium, } \\
\text { and Italy }\end{array}$ & $\begin{array}{l}\text { Beer } \\
\text { Cocoa } \\
\text { Chocolate } \\
\text { Sugar confec- } \\
\quad \text { tionary }\end{array}$ & 1991-1998 & M & SUR & $\begin{array}{l}\text { LCPS in Canada and United States } \\
\text { LCPS in Italy } \\
\text { LCPS in United Kingdom }\end{array}$ \\
\hline Jin & AEL (2008) & Canada & 19 & Wheat & 1988-2003 & A & TWFE & AER: 2/19; CED: 4/19; LCPS: 3/19 \\
\hline
\end{tabular}


Table A1. Continued

\begin{tabular}{|c|c|c|c|c|c|c|c|c|}
\hline Authors & $\begin{array}{l}\text { Journal }^{\mathrm{a}} \\
\text { (year) }\end{array}$ & Exporter & $\begin{array}{l}\text { (Number of) } \\
\text { Importers }\end{array}$ & $\begin{array}{l}\text { (Number of) } \\
\text { Product }\end{array}$ & Period & Data $^{b}$ & $\begin{array}{l}\text { Method/ } \\
\text { Estimator }^{\mathrm{c}}\end{array}$ & Result $^{\mathrm{d}}$ \\
\hline \multirow{5}{*}{$\begin{array}{l}\text { Jin and } \\
\text { Miljkovic }\end{array}$} & \multirow[t]{5}{*}{ JIES (2008) } & \multirow[t]{5}{*}{ United States } & 22 & Wheat & \multirow[t]{5}{*}{ 1989-2004 } & \multirow[t]{5}{*}{ Q } & TWFE & AER: 3/22; CED: 19/22; LCPS: 6/22 \\
\hline & & & 16 & Corn & & & DTWFE & AER: 3/22; CED: 18/22; LCPS: 6/22 \\
\hline & & & \multirow[t]{3}{*}{14} & \multirow[t]{3}{*}{ Soybeans } & & & TWFE & AER: 5/16; CED: 7/16; LCPS: 5/16 \\
\hline & & & & & & & DTWFE & AER: 6/16; CED: 13/16; LCPS: 6/16 \\
\hline & & & & & & & DTWFE & AER: 5/14; CED: 6/14 \\
\hline Fedoseeva & $\begin{array}{l}\text { JAFIO } \\
\qquad(2013)\end{array}$ & Germany & 5 & $\begin{array}{l}\text { Sugar confec- } \\
\text { tionary }\end{array}$ & 1991-2011 & $\mathrm{M}$ & FE & $\begin{array}{l}\text { LCPS in Canada, Switzerland, United } \\
\text { Kingdom, and United States }\end{array}$ \\
\hline Pall & \multirow[t]{3}{*}{ JAE (2013) } & \multirow[t]{3}{*}{ Russia } & \multirow[t]{3}{*}{25} & \multirow[t]{3}{*}{ Wheat } & 2002-2007 & \multirow[t]{3}{*}{ Q } & \multirow[t]{3}{*}{ FE } & CED: 3/25; LCPS: 4/25 \\
\hline Perekhozhuk & & & & & 2008-2010 & & & CED: 3/25; LCPS: 9/25 \\
\hline $\begin{array}{c}\text { Teuber and } \\
\text { Glauben }\end{array}$ & & & & & 2002-2010 & & & AER: 2/15; CED: 2/25; LCPS: 3/25 \\
\hline
\end{tabular}

a AEL, Applied Economics Letters; AER, American Economic Review; AJAE, American Journal of Agricultural Economics; AJARE, Australian Journal of Agricultural and Resource Economics; CJAE, Canadian Journal of Agricultural Economics; E, Empirica; IEJ, International Economic Journal; JAAE, Journal of Agricultural and Applied Economics; JAE, Journal of Agricultural Economics; JAFIO, Journal of Agricultural \& Food Industrial Organization; JARE, Journal of Agricultural and Resource Economics; JIES, Journal of International Economic Studies; RIE, Review of International Economics.

${ }^{\mathrm{b}} \mathrm{A}$, annual; $\mathrm{M}$, monthly; Q, quarterly.

' DTWFE, dynamic two-way fixed effects; FE, fixed effects; GLS, generalized least squares; GMM, generalized method of moments; LAD, least absolute deviations; OLS, ordinary least squares; RCM, random coefficient model; SUR, seemingly unrelated regressions; TWFE, two-way fixed effects.

d AER, evidence of price discrimination via amplification of exchange-rate effects (significant positive exchange rate effect); CED, evidence of price discrimination via constant elasticity of demand (significant country effect); LCPS, evidence of price discrimination via local currency price stability (significant negative exchange rate effect).

Source: Own compilation based on the articles cited. 
Table A2. Descriptive Statistics for Kazakhstan

\begin{tabular}{|c|c|c|c|c|c|c|c|c|c|}
\hline \multirow[b]{2}{*}{ Importing Countries } & \multirow[b]{2}{*}{$\mathrm{N}$} & \multicolumn{4}{|c|}{ Exchange Rate } & \multicolumn{4}{|c|}{ Export Unit Value } \\
\hline & & Mean & $\mathrm{CV}$ & Min. & Max. & Mean & $\mathrm{CV}$ & Min. & Max. \\
\hline Afghanistan & 17 & 0.41 & 0.30 & 0.31 & 0.71 & 20,512 & 0.49 & 6,472 & 42,686 \\
\hline Albania & 4 & 0.71 & 0.03 & 0.69 & 0.74 & 32,643 & 0.41 & 16,593 & 49,577 \\
\hline Algeria & 5 & 0.64 & 0.22 & 0.52 & 0.81 & 59,328 & 1.58 & 11,374 & 226,726 \\
\hline Azerbaijan & 17 & 0.01 & 0.28 & 0.01 & 0.01 & 19,175 & 0.43 & 8,085 & 37,084 \\
\hline Belarus & 14 & 15.34 & 0.99 & 0.20 & 56.50 & 21,549 & 0.53 & 7,757 & 44,677 \\
\hline China & 7 & 0.05 & 0.20 & 0.04 & 0.07 & 57,439 & 1.49 & 8,728 & 249,397 \\
\hline Cyprus & 4 & 0.01 & 0.26 & 0.00 & 0.01 & 12,664 & 0.32 & 8,220 & 18,124 \\
\hline Dominica & 5 & 0.03 & 0.34 & 0.02 & 0.04 & 11,109 & 0.22 & 7,830 & 14,048 \\
\hline Egypt & 9 & 0.04 & 0.15 & 0.03 & 0.05 & 20,944 & 0.48 & 6,834 & 35,562 \\
\hline Estonia & 10 & 0.13 & 0.30 & 0.09 & 0.18 & 12,966 & 0.39 & 7,437 & 21,663 \\
\hline Finland & 10 & 0.01 & 0.29 & 0.01 & 0.01 & 26,008 & 0.49 & 11,784 & 51,387 \\
\hline Georgia & 16 & 0.01 & 0.14 & 0.01 & 0.02 & 20,533 & 0.47 & 6,052 & 40,177 \\
\hline Germany & 8 & 0.01 & 0.40 & 0.01 & 0.01 & 25,251 & 0.44 & 10,192 & 39,700 \\
\hline Greece & 12 & 0.01 & 0.29 & 0.01 & 0.01 & 25,097 & 0.48 & 6,183 & 41,249 \\
\hline Indonesia & 4 & 66.33 & 0.13 & 57.34 & 74.59 & 18,393 & 0.22 & 12,828 & 21,566 \\
\hline Iran & 14 & 50.16 & 0.55 & 11.95 & 81.98 & 20,567 & 0.39 & 10,020 & 36,002 \\
\hline Ireland & 5 & 0.01 & 0.23 & 0.01 & 0.01 & 10,028 & 0.31 & 5,300 & 13,408 \\
\hline Israel & 8 & 0.03 & 0.10 & 0.03 & 0.04 & 20,274 & 0.57 & 10,768 & 45,714 \\
\hline Italy & 17 & 0.01 & 0.33 & 0.01 & 0.01 & 22,652 & 0.57 & 7,892 & 48,576 \\
\hline Jordan & 4 & 0.01 & 0.06 & 0.01 & 0.01 & 20,807 & 0.51 & 11,065 & 35,192 \\
\hline Kyrgyz Republic & 17 & 0.30 & 0.13 & & 0.34 & 18,391 & 0.48 & & 34,404 \\
\hline Latvia & 13 & 0.01 & 0.35 & 0.01 & 0.01 & 23,264 & 0.59 & 9,292 & 53,048 \\
\hline Lebanon & 8 & 12.12 & 0.26 & 9.84 & 19.36 & 16,563 & 0.46 & 5,571 & 27,325 \\
\hline Libya & 4 & 0.01 & 0.12 & 0.01 & 0.01 & 25,336 & 0.49 & 6,925 & 33,476 \\
\hline Lithuania & 7 & 0.03 & 0.55 & 0.02 & 0.06 & 14,110 & 0.45 & 7,407 & 26,636 \\
\hline Malaysia & 4 & 0.03 & 0.51 & 0.02 & 0.05 & 31,813 & 0.54 & 8,840 & 45,265 \\
\hline Moldova & 4 & 0.09 & 0.08 & 0.09 & 0.10 & 26,083 & 0.55 & 16,581 & 47,359 \\
\hline Mongolia & 14 & 8.93 & 0.13 & 7.24 & 10.74 & 22,514 & 0.50 & 11,188 & 45,724 \\
\hline Morocco & 5 & 0.07 & 0.06 & 0.06 & 0.08 & 18,930 & 0.47 & 9,863 & 33,067 \\
\hline Netherlands & 8 & 0.01 & 0.39 & 0.01 & 0.01 & 98,829 & 1.89 & 8,090 & 559,241 \\
\hline Norway & 13 & 0.05 & 0.16 & 0.04 & 0.07 & 20,915 & 0.40 & 11,140 & 36,618 \\
\hline Pakistan & 5 & 0.46 & 0.18 & 0.38 & 0.59 & 20,045 & 0.48 & 8,973 & 30,831 \\
\hline Poland & 15 & 0.03 & 0.30 & 0.02 & 0.04 & 24,314 & 0.58 & 6,590 & 47,881 \\
\hline Portugal & 5 & 0.01 & 0.16 & 0.01 & 0.01 & 21,428 & 0.61 & 10,764 & 42,958 \\
\hline Romania & 5 & 0.02 & 0.32 & 0.01 & 0.02 & 16,688 & 0.33 & 10,257 & 21,579 \\
\hline Spain & 10 & 0.01 & 0.25 & 0.01 & 0.01 & 16,396 & 0.46 & 7,987 & 33,458 \\
\hline Sudan & 4 & 0.02 & 0.20 & 0.02 & 0.02 & 22,370 & 0.43 & 11,344 & 34,802 \\
\hline Sweden & 10 & 0.06 & 0.28 & 0.04 & 0.10 & 24,555 & 0.46 & 7,607 & 42,211 \\
\hline Switzerland & 10 & 0.01 & 0.31 & 0.01 & 0.02 & 20,295 & 0.53 & 8,949 & 37,866 \\
\hline Tajikistan & 17 & 0.02 & 0.43 & 0.01 & 0.03 & 17,745 & 0.43 & 7,791 & 31,293 \\
\hline Tunisia & 4 & 0.01 & 0.09 & 0.01 & 0.01 & 22,233 & 0.41 & 10,538 & 32,392 \\
\hline Turkey & 17 & 0.01 & 0.45 & 0.00 & 0.01 & 20,311 & 0.47 & 7,704 & 37,776 \\
\hline Turkmenistan & 14 & 0.01 & 0.44 & 0.01 & 0.02 & 22,179 & 0.56 & 8,923 & 50,548 \\
\hline United Arab Emirates & 8 & 0.03 & 0.09 & 0.02 & 0.03 & 22,429 & 0.40 & 11,392 & 38,263 \\
\hline United Kingdom & 12 & 0.01 & 0.24 & 0.00 & 0.01 & 250,766 & 3.07 & 6,792 & $2,700,000$ \\
\hline United States & 7 & 0.01 & 0.30 & 0.01 & 0.01 & 15,969 & 0.25 & 10,431 & 21,548 \\
\hline Uzbekistan & 17 & 0.01 & 0.64 & 0.00 & 0.01 & 18,036 & 0.33 & 9,337 & 31,691 \\
\hline Venezuela & 4 & 0.01 & 0.14 & 0.01 & 0.01 & 38,130 & 1.22 & 12,094 & 107,891 \\
\hline
\end{tabular}

Notes: $\mathrm{N}$ denotes the number of observations; Mean, the mean value of the variable; $\mathrm{CV}$, the coefficient of variation defined as the standard deviation/mean; and Min. and Max., the minimum and maximum values of the variable, respectively. 
Table A3. Descriptive Statistics for Russia

\begin{tabular}{|c|c|c|c|c|c|c|c|c|c|}
\hline \multirow[b]{2}{*}{ Importing Countries } & \multirow[b]{2}{*}{$\mathrm{N}$} & \multicolumn{4}{|c|}{ Exchange Rate } & \multicolumn{4}{|c|}{ Export Unit Value } \\
\hline & & Mean & CV & Min. & Max. & Mean & $\mathrm{CV}$ & Min. & Max. \\
\hline Afghanistan & 4 & 1.68 & 0.14 & 1.51 & 2.02 & 6,154 & 0.42 & 2,821 & 9,146 \\
\hline Albania & 12 & 3.69 & 0.14 & 2.99 & 4.92 & 4,568 & 0.41 & 2,188 & 8,241 \\
\hline Algeria & 9 & 2.56 & 0.05 & 2.29 & 2.71 & 3,270 & 0.22 & 2,421 & 4,222 \\
\hline Armenia & 17 & 25.88 & 0.90 & 11.45 & 84.85 & 4,261 & 0.51 & 650 & 8,272 \\
\hline Austria & 12 & 0.04 & 0.54 & 0.02 & 0.09 & 3,766 & 0.60 & 650 & 7,133 \\
\hline Azerbaijan & 17 & 0.05 & 0.87 & 0.03 & 0.17 & 3,925 & 0.62 & 650 & 9,790 \\
\hline Bangladesh & 7 & 2.47 & 0.09 & 2.18 & 2.76 & 4,896 & 0.24 & 2,942 & 6,112 \\
\hline British Virgin Islands & 4 & 0.09 & 0.78 & 0.03 & 0.17 & 3,041 & 1.25 & 665 & 8,668 \\
\hline Bulgaria & 5 & 0.10 & 1.10 & 0.04 & 0.29 & 3,523 & 0.79 & 589 & 6,779 \\
\hline Cyprus & 14 & 0.03 & 0.78 & 0.02 & 0.09 & 3,981 & 0.60 & 631 & 8,985 \\
\hline Denmark & 8 & 0.33 & 1.01 & 0.18 & 1.14 & 4,831 & 0.71 & 1,151 & 9,759 \\
\hline $\begin{array}{l}\text { Democratic Republic } \\
\text { of Congo }\end{array}$ & 5 & 25.87 & 0.18 & 20.20 & 31.29 & 5,963 & 0.17 & 4,555 & 7,163 \\
\hline Egypt & 12 & 0.19 & 0.15 & 0.14 & 0.22 & 4,742 & 0.43 & 2,477 & 8,892 \\
\hline Eritrea & 6 & 0.54 & 0.12 & 0.45 & 0.62 & 5,061 & 0.26 & 3,407 & 6,288 \\
\hline Estonia & 9 & 1.05 & 0.78 & 0.45 & 2.40 & 1,791 & 0.52 & 469 & 2,828 \\
\hline Ethiopia & 4 & 0.44 & 0.23 & 0.35 & 0.58 & 5,344 & 0.23 & 4,285 & 7,081 \\
\hline Finland & 4 & 0.05 & 0.61 & 0.03 & 0.09 & 3,093 & 0.54 & 1,640 & 5,455 \\
\hline Georgia & 17 & 0.09 & 0.66 & 0.05 & 0.25 & 3,936 & 0.57 & 691 & 8,706 \\
\hline Germany & 9 & 0.03 & 0.18 & 0.02 & 0.04 & 4,582 & 0.46 & 1,964 & 7,839 \\
\hline Greece & 16 & 0.04 & 0.79 & 0.02 & 0.14 & 3,741 & 0.58 & 621 & 8,086 \\
\hline Hungary & 5 & 14.87 & 0.71 & 6.93 & 29.81 & 3,243 & 1.05 & 291 & 8,748 \\
\hline India & 7 & 1.63 & 0.06 & 1.51 & 1.75 & 6,178 & 0.34 & 3,428 & 8,768 \\
\hline Indonesia & 8 & 329.35 & 0.11 & 279.46 & 390.26 & 5,010 & 0.35 & 3,161 & 7,993 \\
\hline Iran & 10 & 321.82 & 0.16 & 220.33 & 388.58 & 4,630 & 0.56 & 2,038 & 9,450 \\
\hline Iraq & 10 & 58.26 & 0.58 & 21.24 & 123.65 & 4,636 & 0.64 & 753 & 9,326 \\
\hline Israel & 17 & 0.21 & 0.75 & 0.12 & 0.62 & 3,438 & 0.65 & 550 & 7,993 \\
\hline Italy & 15 & 0.04 & 0.84 & 0.02 & 0.15 & 3,692 & 0.66 & 417 & 9,357 \\
\hline Japan & 4 & 2.78 & 0.06 & 2.58 & 2.95 & 7,161 & 0.16 & 6,134 & 8,582 \\
\hline Jordan & 9 & 0.03 & 0.09 & 0.02 & 0.03 & 5,541 & 0.38 & 2,885 & 8,799 \\
\hline Kenya & 9 & 2.66 & 0.06 & 2.44 & 3.02 & 5,630 & 0.32 & 3,284 & 8,179 \\
\hline Kyrgyz Republic & 9 & 1.84 & 0.32 & 1.35 & 3.00 & 9,360 & 1.10 & 625 & 29,970 \\
\hline Latvia & 10 & 0.04 & 0.91 & 0.02 & 0.11 & 4,911 & 0.91 & 291 & 14,065 \\
\hline Lebanon & 15 & 76.73 & 0.90 & 47.50 & 306.87 & 3,900 & 0.55 & 767 & 8,179 \\
\hline Libya & 11 & 0.04 & 0.09 & 0.04 & 0.05 & 4,773 & 0.46 & 1,944 & 8,520 \\
\hline Lithuania & 12 & 0.23 & 1.11 & 0.08 & 0.78 & 3,936 & 0.73 & 764 & 8,844 \\
\hline Malaysia & 5 & 0.12 & 0.13 & 0.10 & 0.13 & 5,514 & 0.26 & 3,111 & 6,651 \\
\hline Malta & 4 & 0.02 & 0.51 & 0.01 & 0.04 & 2,797 & 0.72 & 689 & 5,542 \\
\hline Mauritania & 6 & 9.44 & 0.07 & 8.27 & 10.11 & 6,151 & 0.38 & 3,140 & 8,706 \\
\hline Moldova & 12 & 0.50 & 0.34 & 0.35 & 0.90 & 7,973 & 1.07 & 553 & 25,964 \\
\hline Mongolia & 16 & 50.62 & 0.51 & 35.42 & 136.56 & 4,558 & 0.45 & 1,064 & 8,599 \\
\hline Morocco & 15 & 0.45 & 0.84 & 0.25 & 1.65 & 4,170 & 0.63 & 776 & 9,636 \\
\hline Mozambique & 6 & 0.97 & 0.09 & 0.87 & 1.12 & 6,399 & 0.24 & 4,459 & 8,489 \\
\hline Netherlands & 5 & 0.03 & 0.19 & 0.03 & 0.04 & 4,119 & 0.76 & 1,477 & 8,080 \\
\hline Nigeria & 6 & 4.69 & 0.11 & 3.80 & 5.25 & 4,815 & 0.51 & 2,602 & 8,830 \\
\hline North Korea & 7 & 2.88 & 0.91 & 0.07 & 5.63 & 6,046 & 0.71 & 757 & 12,664 \\
\hline
\end{tabular}


Table A3. Continued

\begin{tabular}{|c|c|c|c|c|c|c|c|c|c|}
\hline \multirow[b]{2}{*}{ Importing Countries } & \multirow[b]{2}{*}{$\mathrm{N}$} & \multicolumn{4}{|c|}{ Exchange Rate } & \multicolumn{4}{|c|}{ Export Unit Value } \\
\hline & & Mean & $\mathrm{CV}$ & Min. & Max. & Mean & $\mathrm{CV}$ & Min. & Max. \\
\hline Norway & 8 & 0.21 & 0.10 & 0.19 & 0.24 & 4,855 & 0.44 & 2,363 & 7,746 \\
\hline Oman & 8 & 0.01 & 0.09 & 0.01 & 0.02 & 6,349 & 0.31 & 3,281 & 9,419 \\
\hline Pakistan & 7 & 3.03 & 0.60 & 2.02 & 7.11 & 4,455 & 0.54 & 1,221 & 8,186 \\
\hline Peru & 6 & 0.10 & 0.13 & 0.08 & 0.12 & 6,078 & 0.42 & 2,915 & 9,357 \\
\hline Poland & 11 & 0.23 & 0.76 & 0.10 & 0.57 & 4,029 & 0.64 & 743 & 8,198 \\
\hline Republic of Yemen & 9 & 7.12 & 0.08 & 6.39 & 8.04 & 5,505 & 0.35 & 3,170 & 8,861 \\
\hline Romania & 5 & 0.11 & 0.06 & 0.10 & 0.11 & 4,278 & 0.33 & 2,659 & 6,498 \\
\hline Rwanda & 6 & 20.04 & 0.08 & 17.90 & 22.00 & 6,274 & 0.16 & 5,372 & 7,931 \\
\hline Saudi Arabia & 7 & 0.13 & 0.09 & 0.12 & 0.15 & 4,180 & 0.50 & 1,756 & 6,785 \\
\hline Spain & 10 & 0.03 & 0.16 & 0.02 & 0.04 & 4,169 & 0.57 & 1,809 & 8,613 \\
\hline South Korea & 10 & 50.18 & 0.67 & 35.11 & 144.40 & 4,217 & 0.59 & 650 & 8,117 \\
\hline Sudan & 10 & 0.09 & 0.13 & 0.07 & 0.11 & 5,233 & 0.40 & 2,790 & 9,264 \\
\hline Sweden & 4 & 0.41 & 0.65 & 0.26 & 0.82 & 3,342 & 1.00 & 1,145 & 8,314 \\
\hline Switzerland & 10 & 0.09 & 0.96 & 0.03 & 0.25 & 3,728 & 0.82 & 691 & 9,636 \\
\hline Syrian Arab Republic & 11 & 0.39 & 0.09 & 0.35 & 0.45 & 4,691 & 0.38 & 2,854 & 8,644 \\
\hline Tajikistan & 17 & 0.11 & 0.31 & 0.05 & 0.16 & 5,323 & 1.08 & 968 & 21,843 \\
\hline Tanzania & 8 & 46.84 & 0.10 & 39.91 & 53.51 & 5,698 & 0.26 & 3,394 & 7,653 \\
\hline Thailand & 4 & 1.04 & 0.03 & 1.00 & 1.08 & 5,915 & 0.23 & 4,761 & 7,746 \\
\hline Tunisia & 14 & 0.05 & 0.37 & 0.04 & 0.12 & 4,462 & 0.49 & 1,398 & 8,830 \\
\hline Turkey & 17 & 0.04 & 0.34 & 0.02 & 0.06 & 3,675 & 0.62 & 613 & 8,272 \\
\hline Turkmenistan & 8 & 0.08 & 0.56 & 0.03 & 0.14 & 12,071 & 0.95 & 592 & 32,531 \\
\hline Uganda & 7 & 72.17 & 0.11 & 63.97 & 85.86 & 6,256 & 0.20 & 5,139 & 8,179 \\
\hline United Arab Emirates & 8 & 0.13 & 0.09 & 0.12 & 0.15 & 5,742 & 0.34 & 2,942 & 8,985 \\
\hline United Kingdom & 6 & 0.02 & 0.10 & 0.02 & 0.03 & 6,018 & 0.98 & 1,600 & 17,362 \\
\hline Uzbekistan & 17 & 0.03 & 0.58 & 0.01 & 0.06 & 17,915 & 0.48 & 1,510 & 29,487 \\
\hline Vietnam & 8 & 580.52 & 0.13 & 487.41 & 696.03 & 4,304 & 0.44 & 2,038 & 8,139 \\
\hline
\end{tabular}

Notes: $\mathrm{N}$ denotes the number of observations; Mean, the mean value of the variable; $\mathrm{CV}$, the coefficient of variation defined as the standard deviation/mean; and Min. and Max., the minimum and maximum values of the variable, respectively. 
Table A4. Descriptive Statistics for Ukraine

\begin{tabular}{|c|c|c|c|c|c|c|c|c|c|}
\hline \multirow[b]{2}{*}{ Importing Countries } & \multirow[b]{2}{*}{$\mathrm{N}$} & \multicolumn{4}{|c|}{ Exchange Rate } & \multicolumn{4}{|c|}{ Export Unit Value } \\
\hline & & Mean & $\mathrm{CV}$ & Min. & Max. & Mean & $\mathrm{CV}$ & Min. & Max. \\
\hline Albania & 12 & 19.69 & 0.34 & 12.19 & 33.34 & 1,031 & 0.65 & 359 & 2,430 \\
\hline Algeria & 13 & 14.08 & 0.40 & 9.15 & 31.00 & 812 & 0.70 & 218 & 1,976 \\
\hline Armenia & 15 & 97.38 & 0.56 & 46.63 & 226.32 & 1,026 & 0.70 & 274 & 2,366 \\
\hline Austria & 9 & 0.14 & 0.37 & 0.09 & 0.23 & 1,099 & 0.62 & 335 & 2,159 \\
\hline Azerbaijan & 8 & 0.21 & 0.58 & 0.10 & 0.47 & 859 & 0.91 & 191 & 2,568 \\
\hline Bangladesh & 10 & 12.20 & 0.25 & 8.78 & 19.15 & 865 & 0.60 & 169 & 1,904 \\
\hline Belarus & 17 & 336.56 & 0.76 & 7.23 & $1,040.40$ & 938 & 0.82 & 86 & 2,518 \\
\hline Belgium & 6 & 0.17 & 0.30 & 0.09 & 0.23 & 604 & 0.42 & 339 & 1,001 \\
\hline Bermuda & 4 & 0.34 & 0.47 & 0.19 & 0.54 & 295 & 0.45 & 171 & 457 \\
\hline British Virgin Islands & 6 & 0.23 & 0.38 & 0.18 & 0.41 & 477 & 0.42 & 189 & 788 \\
\hline Bulgaria & 4 & 0.22 & 0.47 & 0.10 & 0.31 & 1,068 & 0.75 & 295 & 2,167 \\
\hline Cyprus & 10 & 0.13 & 0.49 & 0.07 & 0.28 & 641 & 0.80 & 169 & 1,930 \\
\hline Djibouti & 4 & 31.61 & 0.19 & 22.81 & 35.19 & 773 & 0.36 & 545 & 1,161 \\
\hline Egypt & 13 & 0.92 & 0.20 & 0.71 & 1.17 & 997 & 0.64 & 355 & 2,201 \\
\hline Eritrea & 6 & 2.71 & 0.13 & 2.11 & 3.05 & 633 & 0.13 & 575 & 790 \\
\hline Estonia & 10 & 3.90 & 0.51 & 1.53 & 7.46 & 589 & 0.97 & 184 & 2,114 \\
\hline France & 8 & 0.20 & 0.39 & 0.09 & 0.37 & 686 & 1.09 & 198 & 2,510 \\
\hline Georgia & 16 & 0.38 & 0.41 & 0.21 & 0.70 & 1,037 & 0.77 & 203 & 2,473 \\
\hline Germany & 11 & 0.17 & 0.49 & 0.09 & 0.37 & 887 & 0.69 & 206 & 2,138 \\
\hline Greece & 10 & 0.15 & 0.25 & 0.09 & 0.21 & 1,020 & 0.71 & 451 & 2,382 \\
\hline Hungary & 12 & 46.20 & 0.34 & 25.97 & 87.53 & 586 & 0.42 & 176 & 1,053 \\
\hline India & 5 & 9.64 & 0.46 & 5.76 & 16.84 & 734 & 0.66 & 164 & 1,278 \\
\hline Indonesia & 10 & $1,533.52$ & 0.21 & $1,100.77$ & $1,893.71$ & 1,095 & 0.61 & 410 & 2,257 \\
\hline Iraq & 5 & 259.22 & 0.55 & 145.12 & 489.89 & 834 & 0.70 & 203 & 1,667 \\
\hline Ireland & 8 & 0.22 & 0.50 & 0.13 & 0.43 & 698 & 0.80 & 233 & 1,938 \\
\hline Israel & 17 & 0.91 & 0.47 & 0.45 & 1.85 & 752 & 0.76 & 173 & 1,986 \\
\hline Italy & 13 & 0.15 & 0.31 & 0.03 & 0.23 & 861 & 0.64 & 322 & 1,994 \\
\hline Jordan & 11 & 0.12 & 0.23 & 0.09 & 0.17 & 1,093 & 0.57 & 388 & 2,257 \\
\hline Kenya & 10 & 12.60 & 0.16 & 9.93 & 14.78 & 1,168 & 0.56 & 474 & 2,209 \\
\hline Latvia & 6 & 0.20 & 0.49 & 0.09 & 0.31 & 428 & 0.60 & 216 & 917 \\
\hline Lebanon & 13 & 331.15 & 0.57 & 189.01 & 826.92 & 988 & 0.70 & 211 & 2,191 \\
\hline Libya & 10 & 0.21 & 0.22 & 0.15 & 0.26 & 1,069 & 0.67 & 368 & 2,239 \\
\hline Lithuania & 6 & 1.13 & 0.74 & 0.34 & 2.19 & 922 & 0.82 & 253 & 2,130 \\
\hline Malaysia & 9 & 0.67 & 0.57 & 0.38 & 1.60 & 1,184 & 0.64 & 167 & 2,401 \\
\hline Mauritania & 11 & 45.63 & 0.16 & 33.68 & 53.19 & 883 & 0.70 & 410 & 2,130 \\
\hline Moldova & 17 & 2.19 & 0.20 & 1.43 & 2.62 & 1,746 & 0.91 & 313 & 5,615 \\
\hline Morocco & 13 & 1.82 & 0.42 & 1.02 & 3.92 & 882 & 0.73 & 191 & 2,313 \\
\hline Myanmar & 4 & 1.01 & 0.24 & 0.78 & 1.22 & 1,299 & 0.67 & 589 & 2,433 \\
\hline Netherlands & 13 & 0.17 & 0.46 & 0.09 & 0.37 & 961 & 0.68 & 159 & 2,287 \\
\hline Nigeria & 7 & 22.38 & 0.12 & 18.81 & 25.46 & 697 & 0.39 & 389 & 1,079 \\
\hline North Korea & 13 & 256.42 & 0.52 & 140.81 & 572.12 & 702 & 0.81 & 174 & 2,201 \\
\hline Peru & 4 & 0.65 & 0.01 & 0.64 & 0.66 & 622 & 0.17 & 501 & 758 \\
\hline Philippines & 9 & 9.72 & 0.33 & 5.68 & 16.69 & 613 & 0.54 & 191 & 1,222 \\
\hline Poland & 9 & 0.95 & 0.52 & 0.37 & 1.76 & 810 & 0.97 & 194 & 2,590 \\
\hline Portugal & 6 & 0.15 & 0.34 & 0.09 & 0.21 & 1,014 & 0.73 & 403 & 2,040 \\
\hline Republic of Yemen & 8 & 33.21 & 0.18 & 26.04 & 39.40 & 1,089 & 0.56 & 500 & 2,401 \\
\hline
\end{tabular}


Table A4. Continued

\begin{tabular}{|c|c|c|c|c|c|c|c|c|c|}
\hline \multirow[b]{2}{*}{ Importing Countries } & \multirow[b]{2}{*}{$\mathrm{N}$} & \multicolumn{4}{|c|}{ Exchange Rate } & \multicolumn{4}{|c|}{ Export Unit Value } \\
\hline & & Mean & CV & Min. & Max. & Mean & $\mathrm{CV}$ & Min. & Max. \\
\hline Saudi Arabia & 6 & 0.59 & 0.22 & 0.47 & 0.73 & 1,270 & 0.47 & 505 & 1,890 \\
\hline Slovak Republic & 5 & 13.33 & 0.33 & 8.46 & 18.06 & 350 & 0.44 & 203 & 517 \\
\hline South Africa & 6 & 1.35 & 0.25 & 1.03 & 1.98 & 964 & 0.73 & 480 & 2,289 \\
\hline South Korea & 7 & 9.22 & 1.19 & 0.41 & 26.58 & 693 & 0.80 & 162 & 1,611 \\
\hline Spain & 12 & 0.14 & 0.29 & 0.09 & 0.21 & 938 & 0.62 & 410 & 2,066 \\
\hline Sri Lanka & 5 & 16.81 & 0.21 & 13.88 & 20.58 & 1,348 & 0.32 & 948 & 2,088 \\
\hline Sudan & 9 & 0.40 & 0.20 & 0.29 & 0.49 & 1,243 & 0.57 & 523 & 2,321 \\
\hline Switzerland & 13 & 0.29 & 0.61 & 0.11 & 0.68 & 1,169 & 0.98 & 172 & 3,609 \\
\hline Syrian Arab Republic & 10 & 1.93 & 0.24 & 1.41 & 2.72 & 1,101 & 0.55 & 355 & 2,010 \\
\hline Tajikistan & 5 & 0.39 & 0.50 & 0.16 & 0.65 & 712 & 0.71 & 320 & 1,269 \\
\hline Thailand & 4 & 4.02 & 0.07 & 3.83 & 4.40 & 1,594 & 0.29 & 1,198 & 2,058 \\
\hline Tunisia & 14 & 0.25 & 0.29 & 0.17 & 0.47 & 953 & 0.68 & 208 & 2,183 \\
\hline Turkey & 15 & 0.19 & 0.41 & 0.05 & 0.28 & 1,053 & 0.76 & 166 & 2,521 \\
\hline Uganda & 6 & 312.52 & 0.13 & 260.61 & 362.66 & 1,339 & 0.40 & 631 & 2,233 \\
\hline United Arab Emirates & 6 & 0.62 & 0.30 & 0.46 & 0.89 & 1,208 & 0.71 & 343 & 2,465 \\
\hline United Kingdom & 16 & 0.13 & 0.55 & 0.08 & 0.35 & 845 & 0.69 & 181 & 2,135 \\
\hline United States & 10 & 0.25 & 0.49 & 0.18 & 0.55 & 471 & 0.45 & 152 & 955 \\
\hline Uzbekistan & 8 & 0.20 & 0.39 & 0.02 & 0.26 & 2,099 & 0.78 & 335 & 5,634 \\
\hline Vietnam & 7 & $2,751.77$ & 0.16 & $2,190.29$ & $3,375.71$ & 1,241 & 0.51 & 351 & 2,034 \\
\hline
\end{tabular}

Notes: $\mathrm{N}$ denotes the number of observations; Mean, the mean value of the variable; $\mathrm{CV}$, the coefficient of variation defined as the standard deviation/mean; and Min. and Max., the minimum and maximum values of the variable, respectively. 